بررسى شرايط تخليه جت دايرهاى همسو در منابع آب پذيرنده بىنهايت كم عمق

\author{
بهشاد مرداسى و جواد احديان

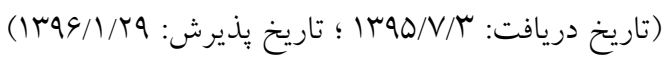

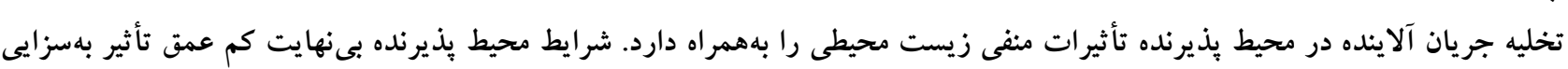

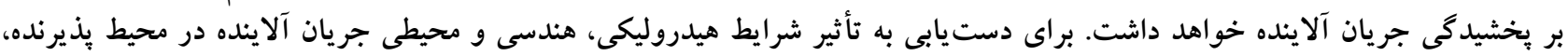

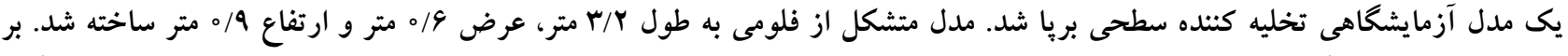

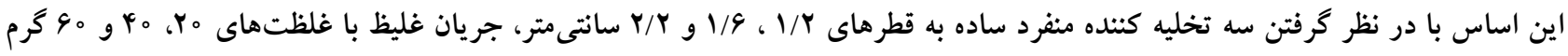

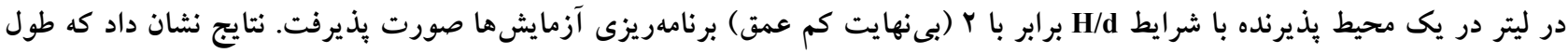

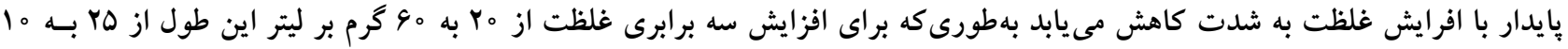

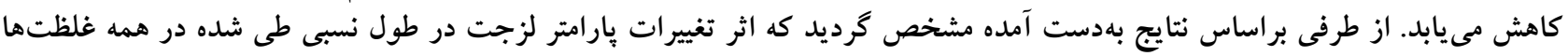

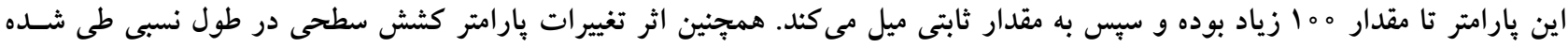

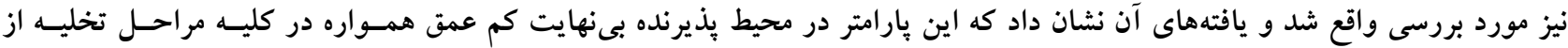

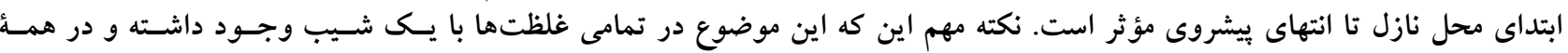

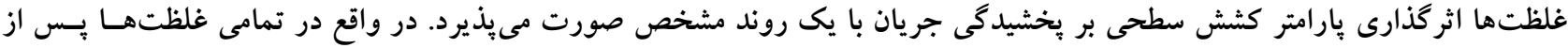

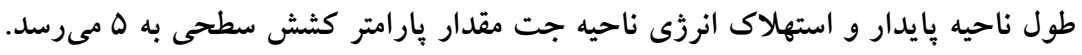

وازههاى كليدى: جت سطحى دايرهاى، بخشيدگى، بىنهايت كم عمق، تغييرات غلظت

ا. كروه سازههاى آبى، دانشكده مهندسى علوم آب، دانشخاه شهيد جِمران اهواز

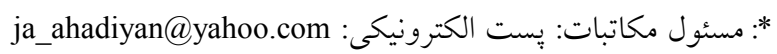




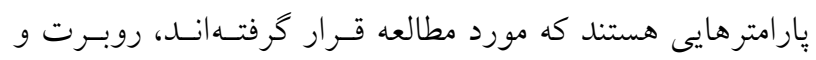

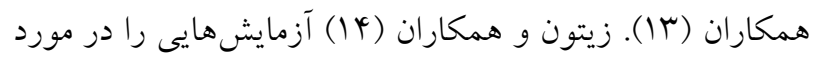

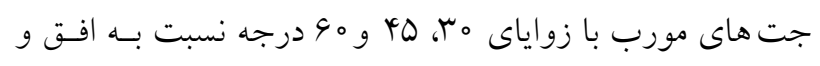

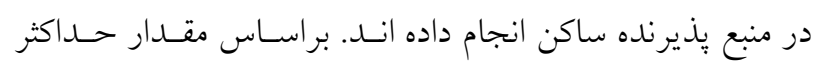

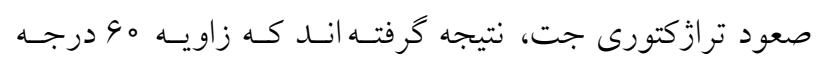

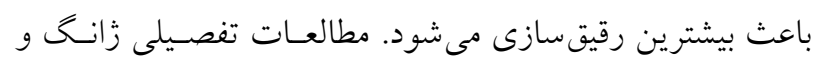

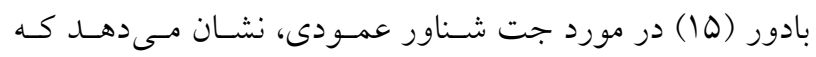

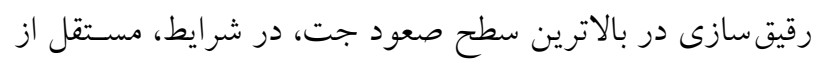

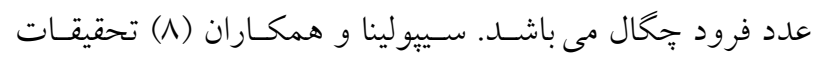

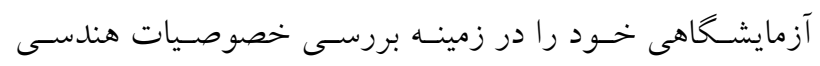

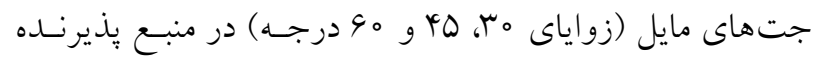

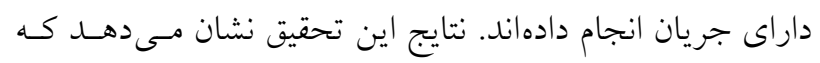

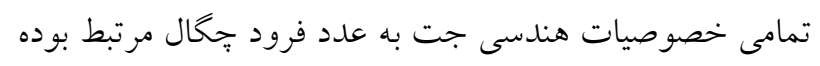

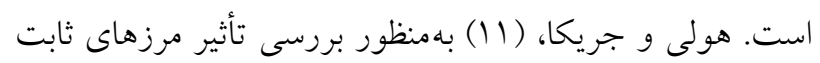

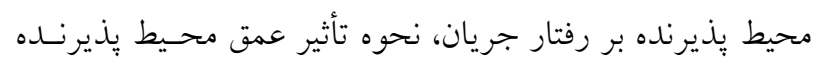

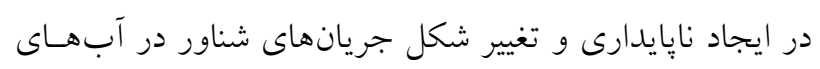

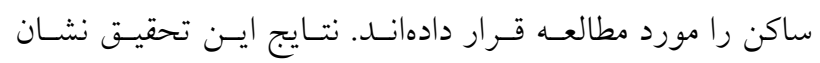

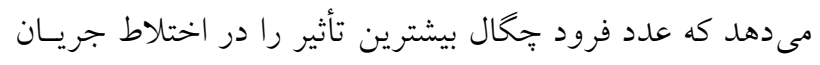
داشته است. در ارتباط با تخليه سطحى فاضلابهاى سنكخين نيز عابسى و همكاران در سال (ه) مطالعات زيادى را برروى تخليه

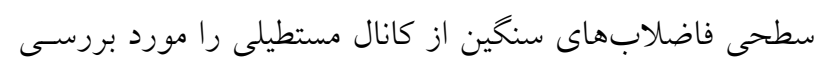

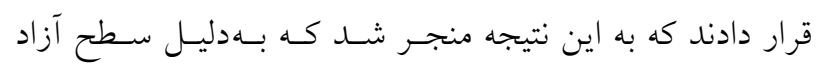

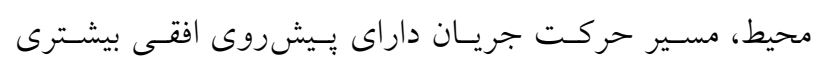

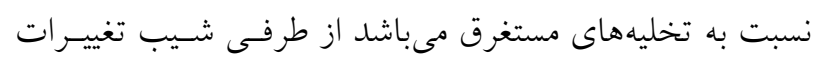

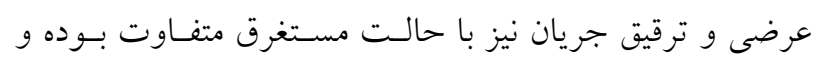

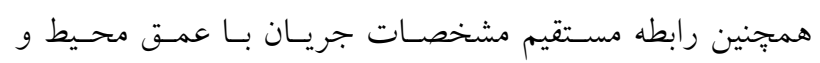

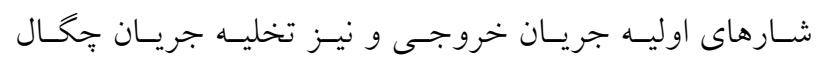

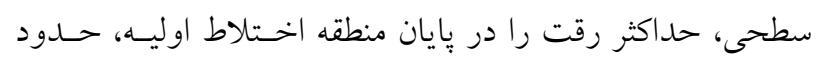

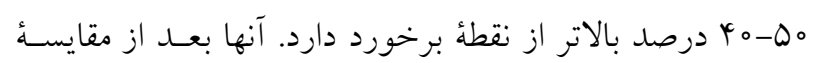

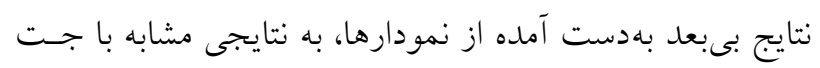

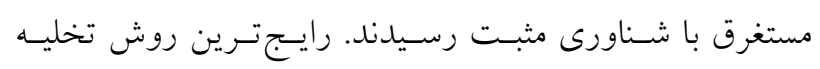

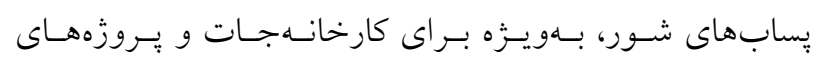

آبهاى سطحى بهعنوان مهم ترين منشاء حيـات در كـره زمسين

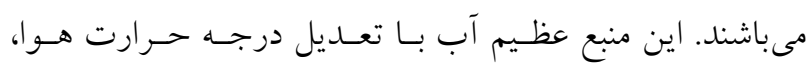

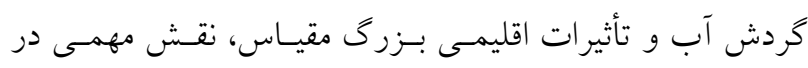

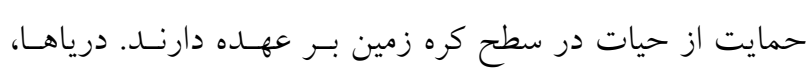

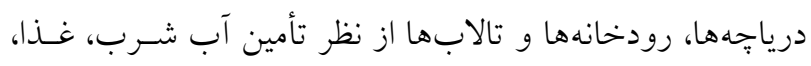

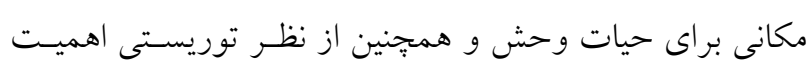
دو جندانى دارند. در مباحث زيست محيطى، منابع آبى همـواره

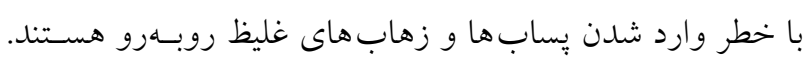

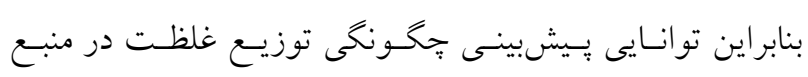

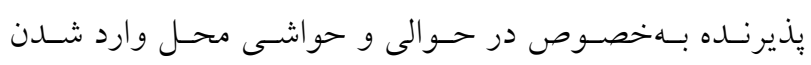

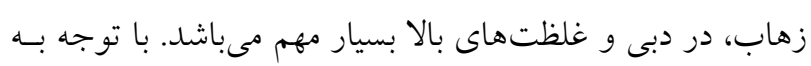

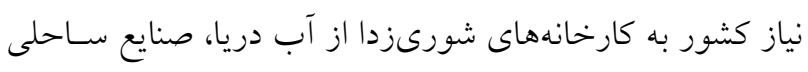

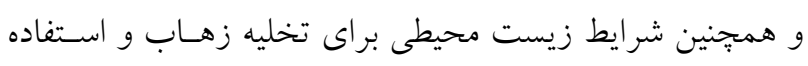

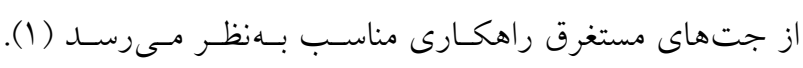

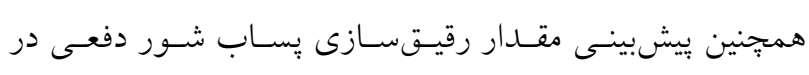

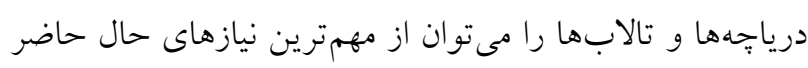

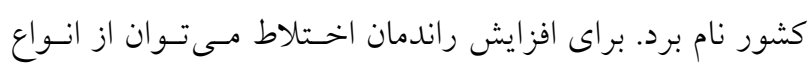
جتها استفاده نمود. جريان جت و يلوم از نظر ظـاهرى تقريبـاً

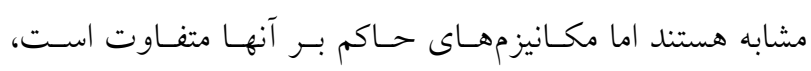

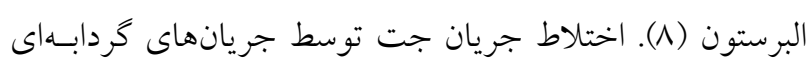

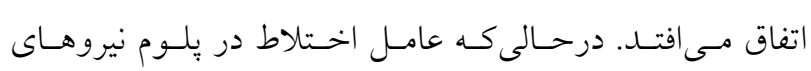

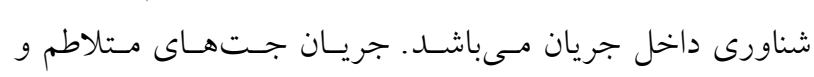

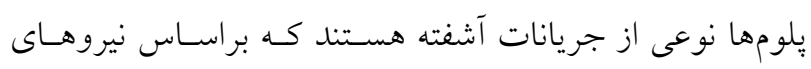

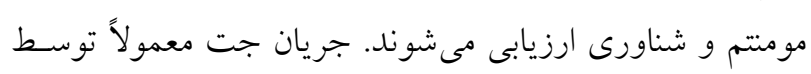
يكى منبع مداوم و تحت تأثير نيروهاى مومنتم انتشـار مسى يابـد، محمدى (Y). در اين زمينه مطالعات زيادى انجـام شــده اسـت.

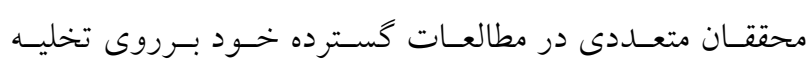
مستغرق فاضلابهاى سنخين، جنبههاى متفاوت حاكم بر رفتـار

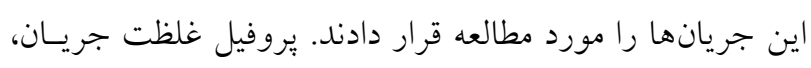

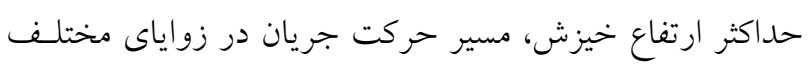

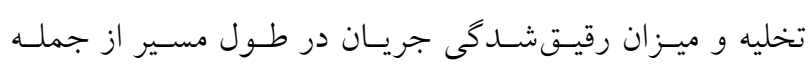


وآب بىنهايت كم عمق تعريف شده است. نسبت عمق به قطر

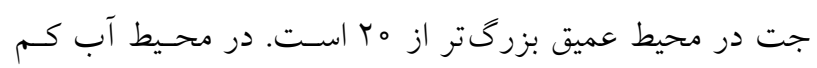

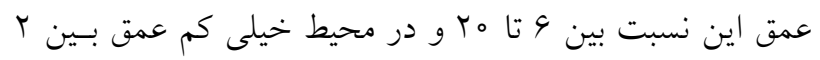

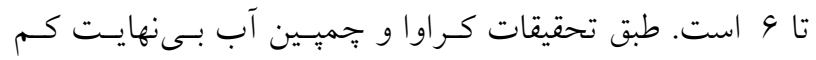

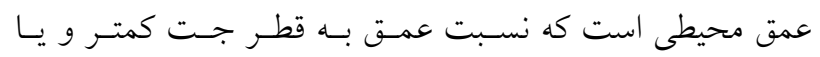

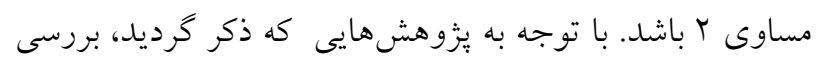

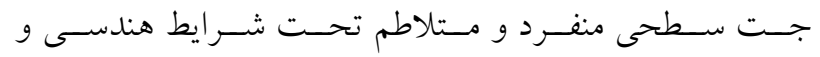

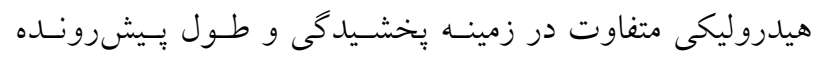
هسته جت به واسطؤ اختلاف غلظت بـين سـيال جـت و و سـيال

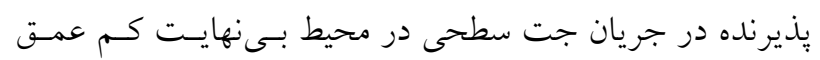

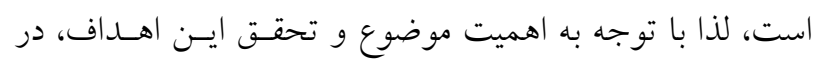

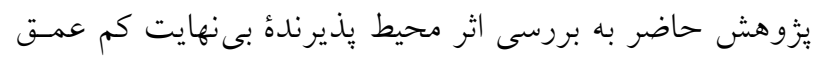

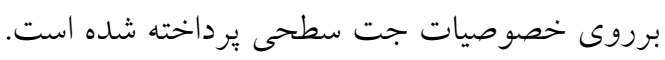

\section{مواد و روش ها}

با توجه به اينكه مطالعـهُ حاضـر، مطالعـه تئسورى آزمايشـخاهى

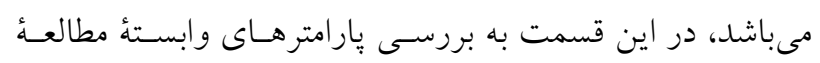

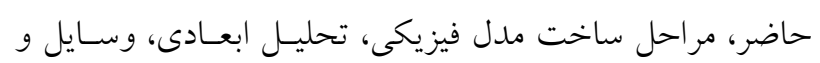

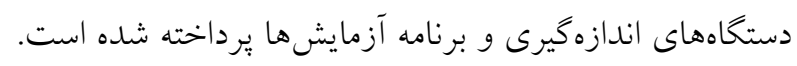

\section{تحليل ابعادى}

با توجه به موقعيت قرارگرفتن نازل جت كه روى سـطح محسيط

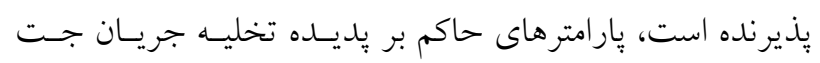

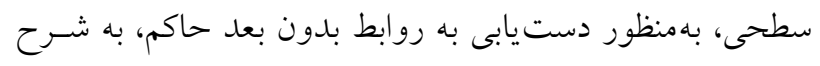

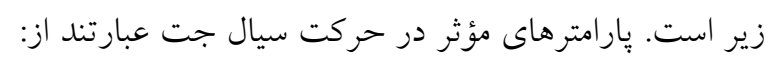
$\mathrm{f}\left(\rho_{\mathrm{a}}, \rho_{\mathrm{j}}, \sigma, \mu_{\mathrm{j}}, \mathrm{u}_{\mathrm{o}}, \mathrm{u}_{\mathrm{m}}, \mathrm{d}, \mathrm{g}, \mathrm{H}, \mathrm{y}, \mathrm{x}, \mathrm{C}_{\mathrm{m}}, \mathrm{C}_{\mathrm{o}}\right)=$ 。

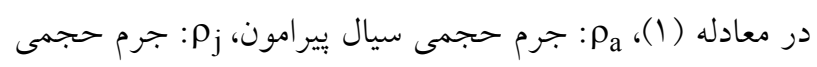

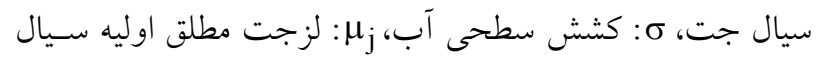

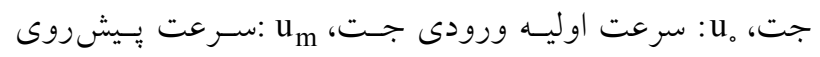

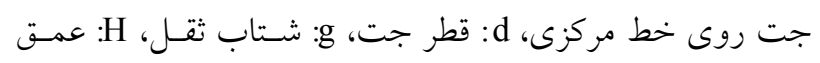

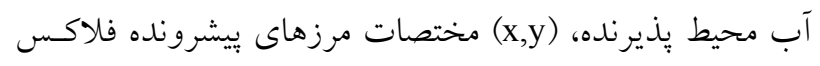
جت، Cl
كوزجى، تخليه توسط انواع تخليه كنندها و كانالهـاى سـاحلى

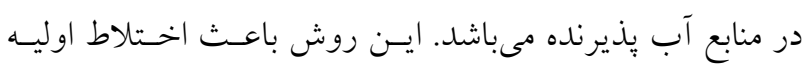

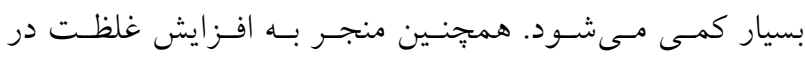

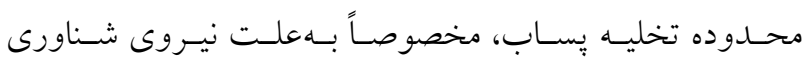

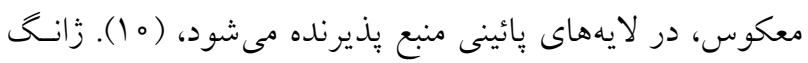

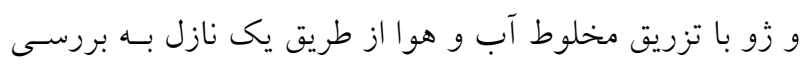

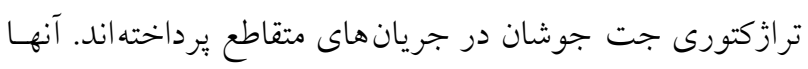

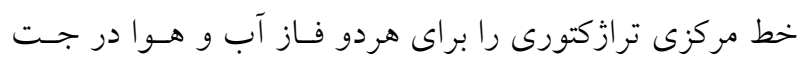

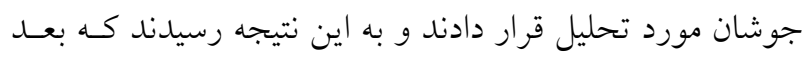

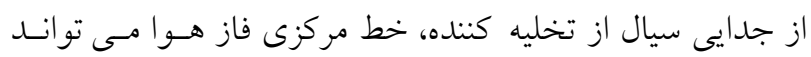
به صورت مستقيم حركت كند و جريان جت بعد از طـى كـردن

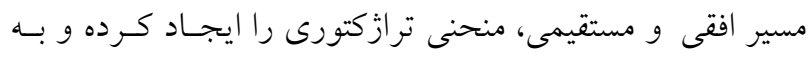

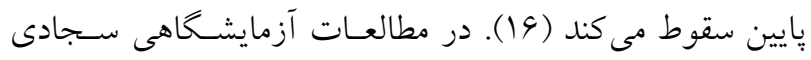

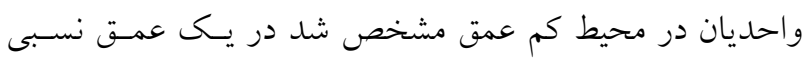

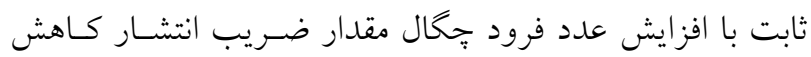

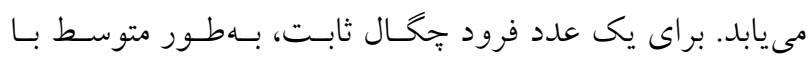
افزايش عمق نسبى مقدار ضريب انتشار افزايش مى يابد. اوليسور

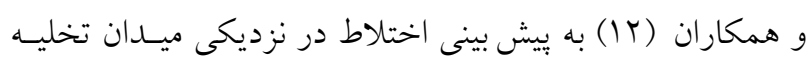

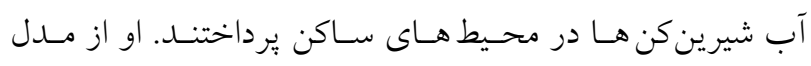

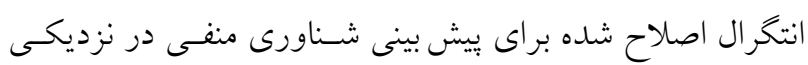

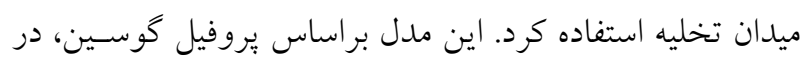

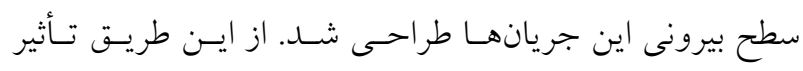

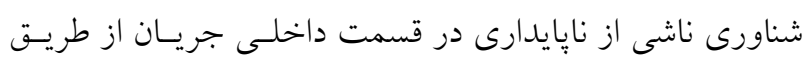

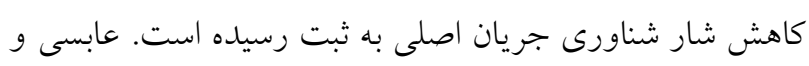

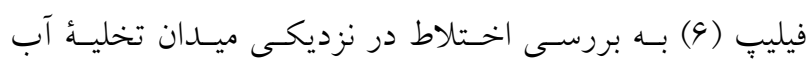

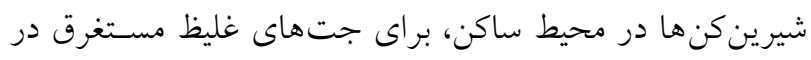

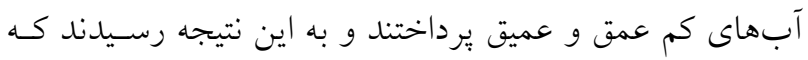

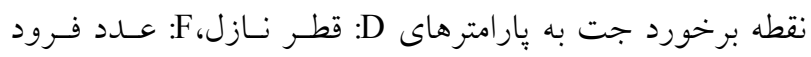

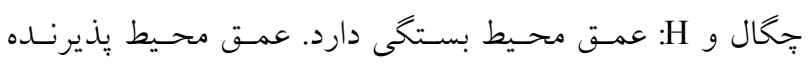

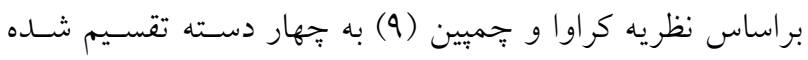

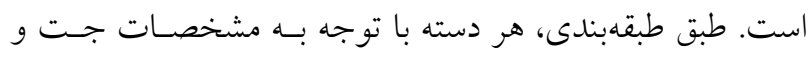

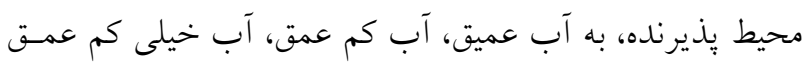




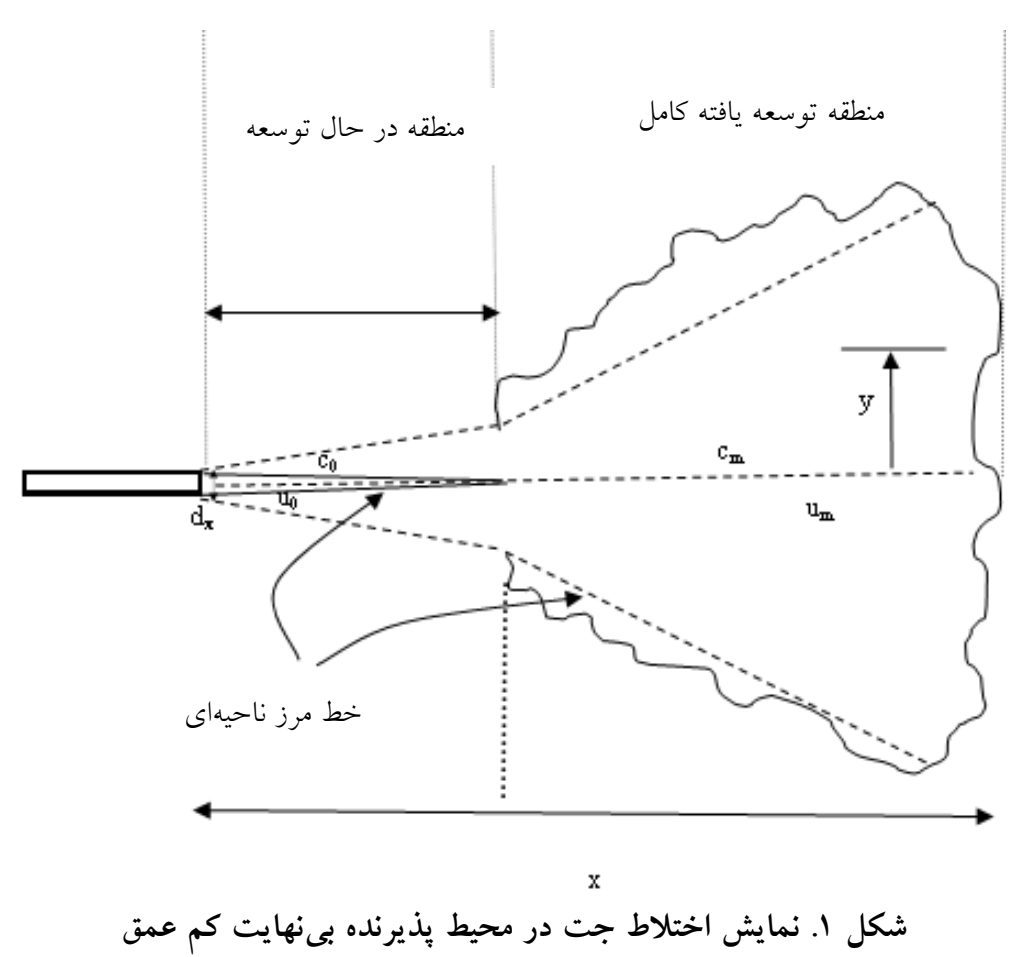

لازم به توضيح است كه بـا توجـهـ بــه اثركـذارى عمـق جريـان

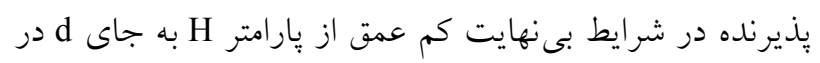

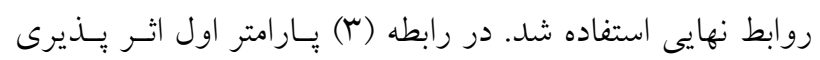

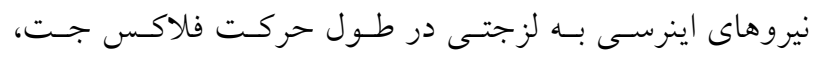

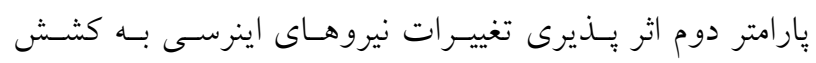

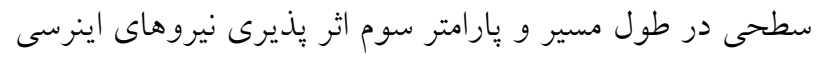

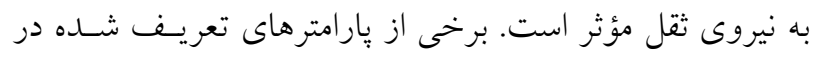

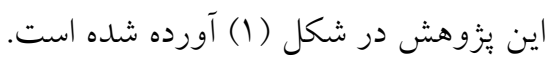

\section{مدل آزمايشگاهى}

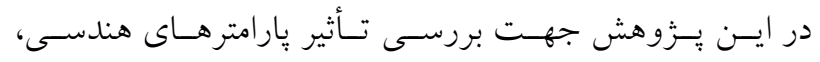

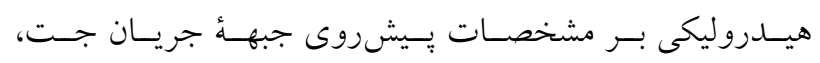

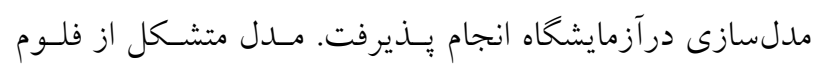

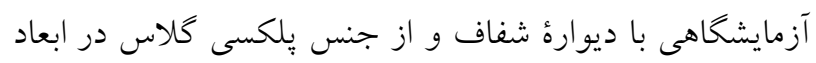

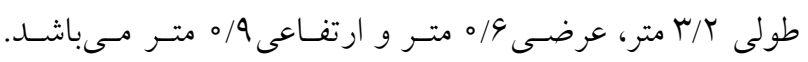

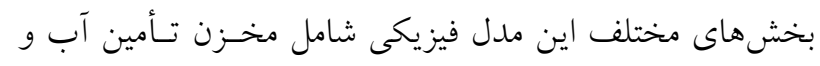

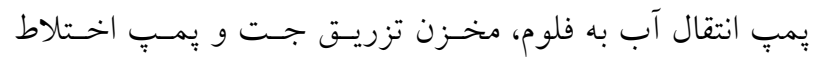

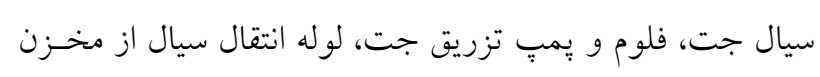

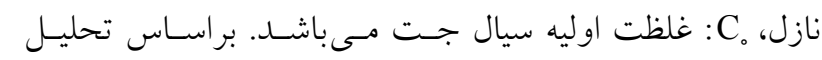

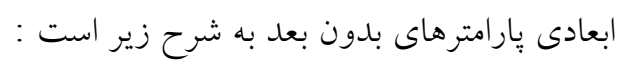
$\mathrm{f}\left(\frac{\Delta \rho}{\rho_{\mathrm{a}}}, \frac{\mathrm{u}_{\mathrm{o}}{ }^{r} \mathrm{H} \rho_{\mathrm{j}}}{\sigma}, \frac{\mathrm{u}_{\mathrm{o}} \mathrm{d} \rho_{\mathrm{j}}}{\mu_{\mathrm{j}}}, \frac{\mathrm{u}_{\mathrm{m}}^{r} \mathrm{H} \Delta \rho}{\sigma}\right.$,

$$
\left.\frac{\mathrm{u}_{\mathrm{m}} \mathrm{H} \Delta \rho}{\mu}, \frac{\mathrm{u}_{\circ}}{\sqrt{\mathrm{g}^{\prime} \cdot \mathrm{d}}}, \frac{\mathrm{c}_{\mathrm{m}}}{\mathrm{c}_{\mathrm{o}}}, \frac{\mathrm{u}_{\mathrm{m}}}{\mathrm{u}_{\circ}}, \frac{\mathrm{x}}{\mathrm{d}}, \frac{\mathrm{y}}{\mathrm{d}}\right)=。
$$

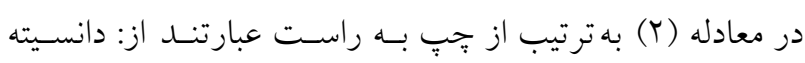

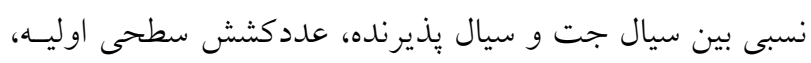

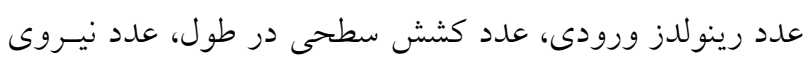

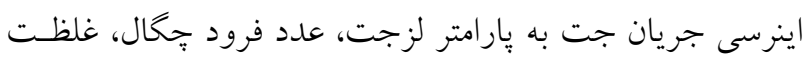

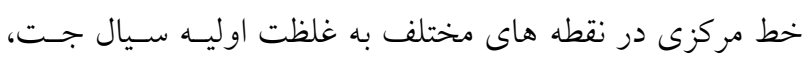

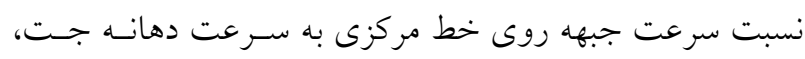

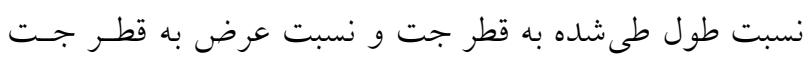

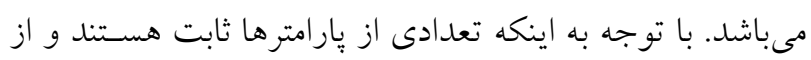

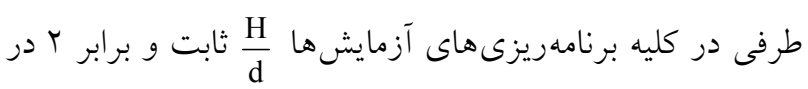

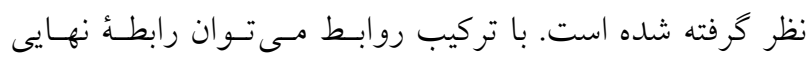
بدون بعد را بهصورت زير نمايش داد: $\mathrm{f}\left(\frac{\mathrm{u}_{\mathrm{m}} \mathrm{H} \Delta \rho}{\mu}, \frac{\mathrm{u}_{\mathrm{m}}^{r} \mathrm{H} \Delta \rho}{\sigma}, \frac{\mathrm{u}_{\mathrm{m}}}{\sqrt{\mathrm{g}^{\prime} \mathrm{d}}}, \frac{\mathrm{c}_{\mathrm{m}}}{\mathrm{c}_{\mathrm{o}}}, \frac{\mathrm{u}_{\mathrm{m}}}{\mathrm{u}_{。}}, \frac{\mathrm{x}}{\mathrm{H}}, \frac{\mathrm{y}}{\mathrm{H}}\right)=。$ 


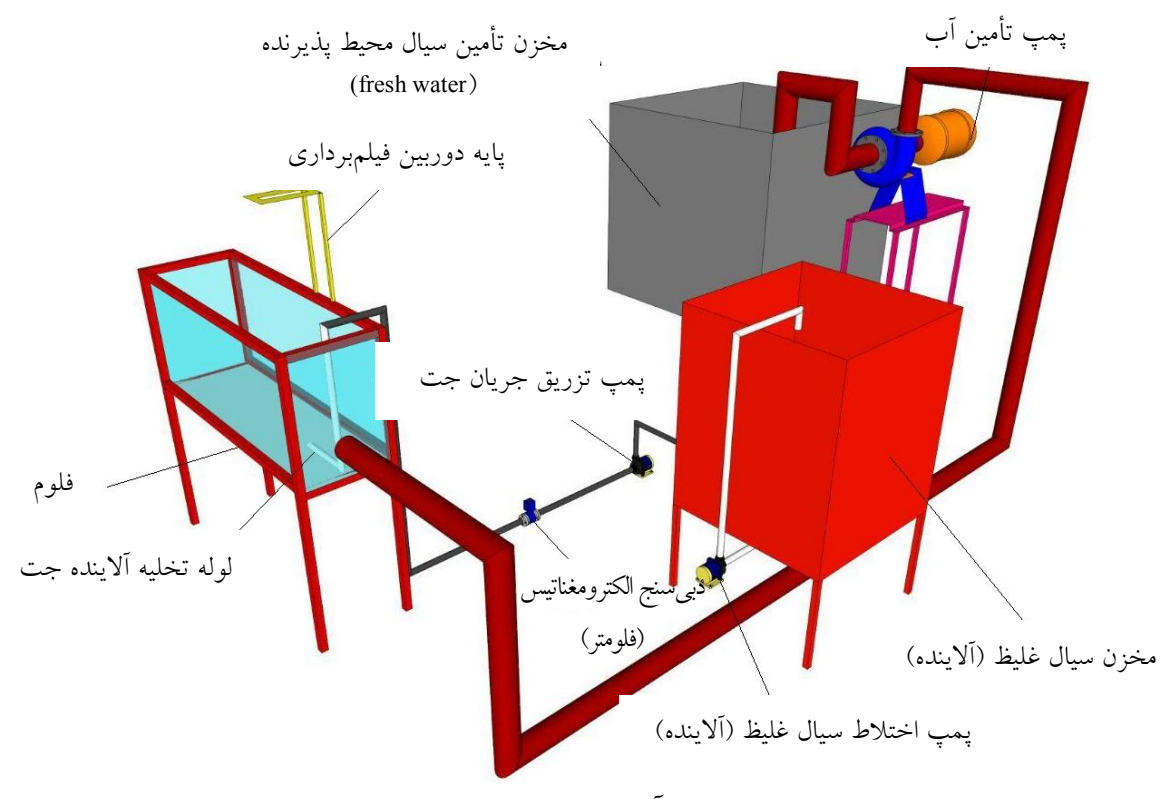

شكل r. نمائى شماتيك از فلوم آزمايشها بههمراه مخزن ذخيره و سيستم جت

اندازه كيرى شد. كـل مـــت زمـان آزمـايش بـهوسـيله دوربسين ديجيتـال CANOON-G31 بــا كيفيـت سـى فــرم بــر ثانيـه فيلمبردارى و ذخيره شد. از طرفى ارتباط بين شورى و دانسـيته تغييرات، دانسيته سـيال تزريست شـونده در طـول فلـوم ثبـت و

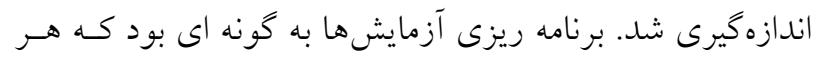

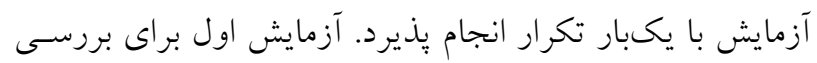

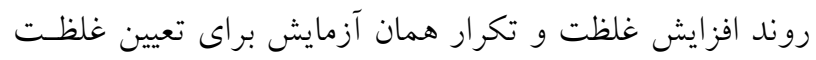
خط مركزى انجام شد. اين كار در تمامى آزمايشها تكرار شـد.

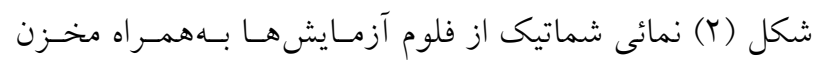
ذخيره و سيستم جت در محيط بىنهايست كـم عمـق را نمـايش مى دهد. شكل (r) نمائى واقعى از فلوم آزمايشها را به تصـوير كشيده است. مطابق با شكل هاى (Y) و (r) ابتدافلوم آزمايشهـا

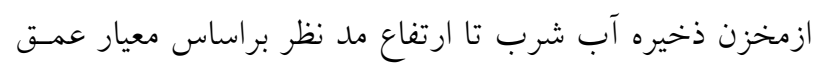

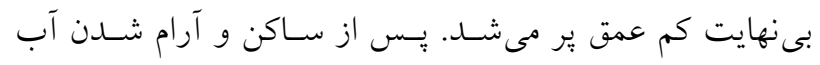
موجود در فلوم بمٍ مربوط به تزريق جريان جت آلاينـده وارد

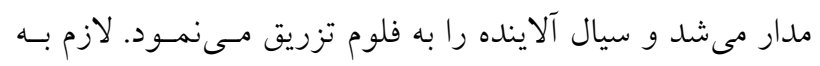

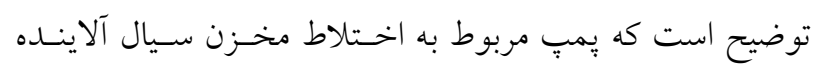

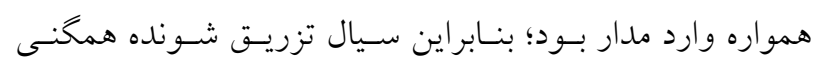
برخوردار بود. بس از تزريق و يخشيدگى سيال آلاينده دادههاى
تزريق به جت، خروجى فلوم و تجهيزات مربوطسه و نـازلهـاى تزريق جت مىباشد. جهت اندازهذيرى دبى خروجسى از مخـزن سيال جت، يك فلومتر الكترومغناطيس با دقت ؟/ه درصد، بعـد از خروجى مخـزن تزريـق شـونده بـا شـرايط اسـتاندارد مـورد

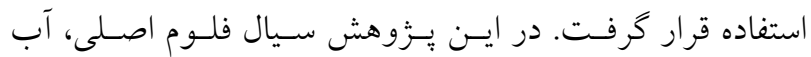
شرب شهرى و سيال تزريق شونده به آن، سيالى با جگالى بالاتر

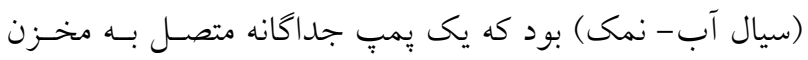
تزريق، وظيفه اختلاط و جرخش سيال مخزن تزريق را برعهـده

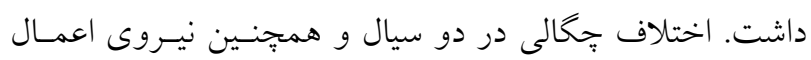
شده به سيال تزريق شونده توسط بمِّ تزريق سبب بِخشـيدگى

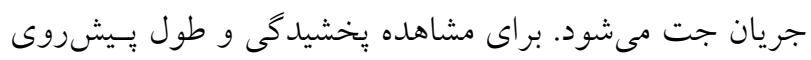

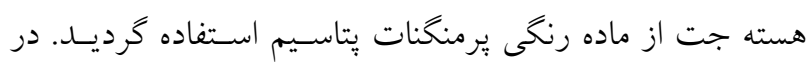
راستاى اهداف تحقيق، فلوم آزمايشها امكان برداشت مختصات جريان خروجى جت را دارا بود. از يك دستگاه EC متسر دقيـق

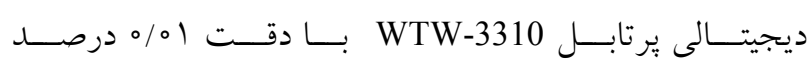
ميكروزيمنس بر سانتى متر كه داراى سنسور اندازه خيرى دما نيـز بود، براى اندازهگيرى EC و دما استفاده شد. مقدار EC و دمـاى لحظهاى آب نمكى مخزن تزريق وآب فلـوم انــازه كيـرى شـــ. غلظتها روى صفحه مشبنـدى شـده در سـه قطر و نـه دبسى 

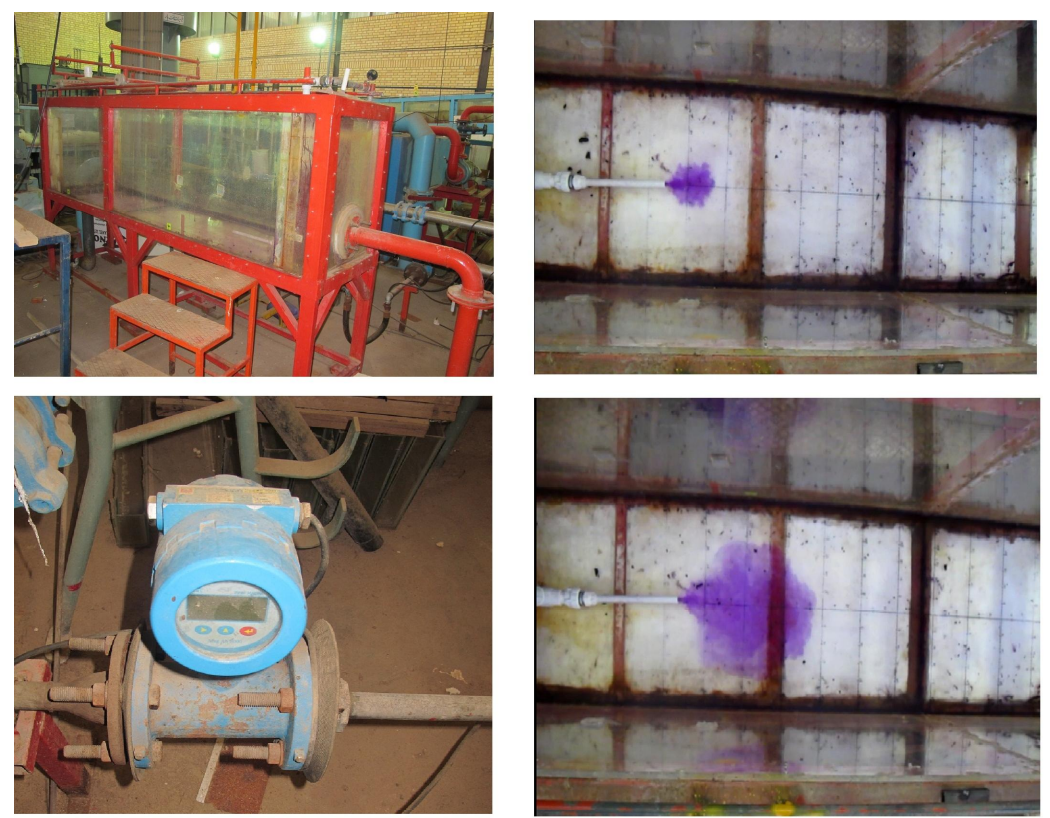

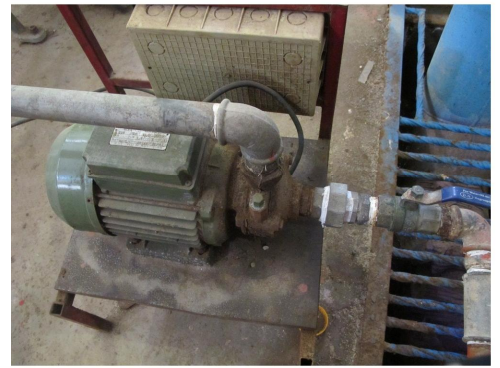

(ب)

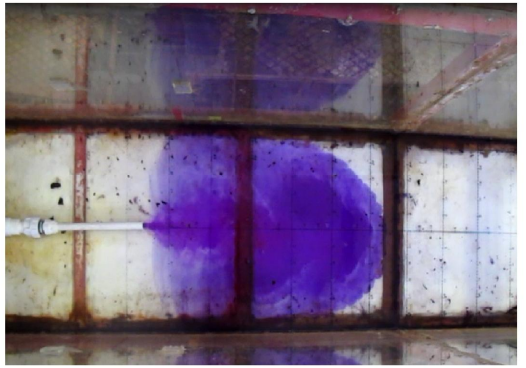

(الف)

شكل r. الف) نمونهاى از اجراى آزمايشها و ب) فلوم و برخى از تجهيزات آزمايشكاهى

طولى است. براى نيل به اهداف تحقيق حاضردر هر آزمايش بـا

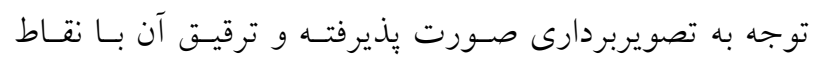

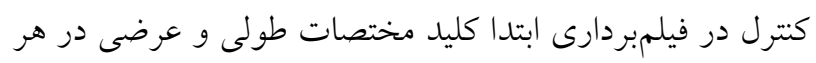

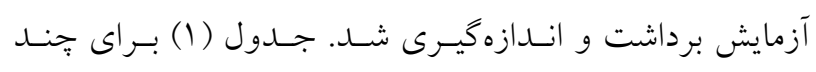

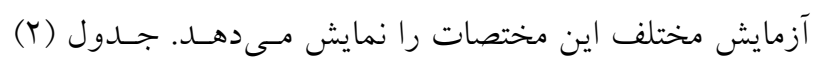

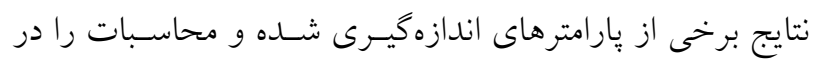

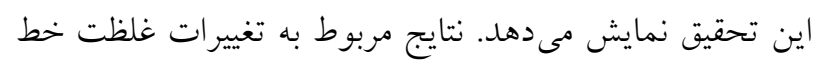

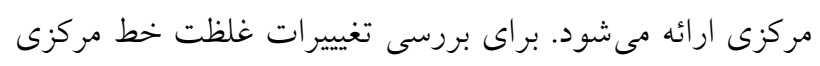

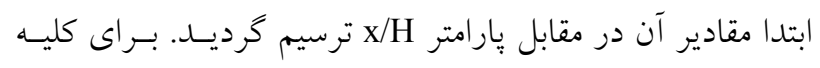

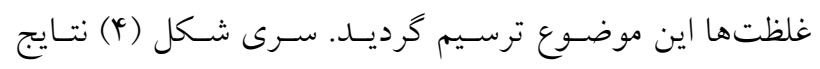
مربوط به اين تغييرات را نمايش مى دهد.

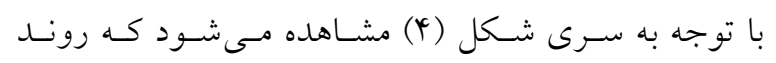

مورد نياز شامل مختصـات حسدود بخخشيدكى در ديـا از بـالا،

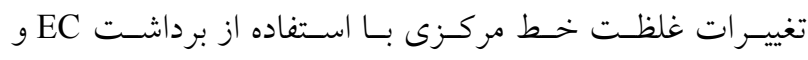

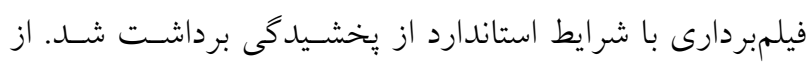
طرفى براى افزايش دقت هر آزمايش دو بار تكـرار مسى گرديسـد.

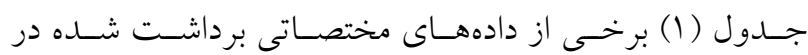
آزمايش هاى اين تحقيق را نمايش مى دهد.

نتايج و بحث

براساس آنجه كه در بخش تحليل ابعادى بيان شد، نتايج تحقيـق

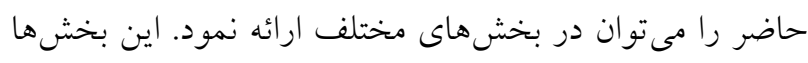

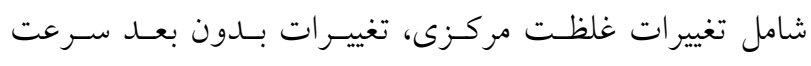

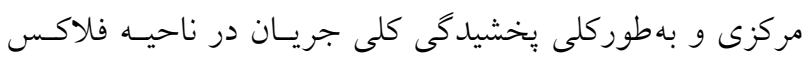


جدول 1. دادههاى مربوط به مختصات طولى و عرضى ناحيه بخشيدگى جريان

\begin{tabular}{|c|c|c|c|c|c|c|c|c|c|c|c|}
\hline \multicolumn{4}{|c|}{$C_{0}=r \circ g / L$} & \multicolumn{4}{|c|}{$\mathrm{C}_{0}=r \circ \mathrm{g} / \mathrm{L}$} & \multicolumn{4}{|c|}{$\mathrm{C}_{0}=9 \circ \mathrm{g} / \mathrm{L}$} \\
\hline \multirow{2}{*}{\multicolumn{2}{|c|}{ 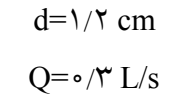 }} & \multicolumn{2}{|c|}{$\mathrm{d}=1 / \mathrm{r} \mathrm{cm}$} & \multicolumn{2}{|c|}{$\mathrm{d}=1 / \pi \mathrm{cm}$} & \multicolumn{2}{|c|}{$\mathrm{d}=1 / 9 \mathrm{~cm}$} & \multicolumn{2}{|c|}{$\mathrm{d}=1 / \tau \mathrm{cm}$} & \multicolumn{2}{|c|}{$\mathrm{D}=1 / 9 \mathrm{~cm}$} \\
\hline & & $\mathrm{Q}=0$, & $\Delta \mathrm{L} / \mathrm{s}$ & $\mathrm{Q}=\mathrm{c}$ & $\mathrm{L} / \mathrm{s}$ & $\mathrm{Q}=0$ & $\Delta \mathrm{L} / \mathrm{s}$ & $\mathrm{Q}=0$ & $\mathrm{~L} / \mathrm{s}$ & $\mathrm{Q}=$ 。 & $4 \mathrm{~L} / \mathrm{s}$ \\
\hline $\mathrm{x} / \mathrm{H}$ & $\mathrm{y} / \mathrm{H}$ & $\mathrm{x} / \mathrm{H}$ & $\mathrm{y} / \mathrm{H}$ & $\mathrm{x} / \mathrm{H}$ & $\mathrm{y} / \mathrm{H}$ & $\mathrm{x} / \mathrm{H}$ & $\mathrm{y} / \mathrm{H}$ & $\mathrm{x} / \mathrm{H}$ & $\mathrm{y} / \mathrm{H}$ & $\mathrm{x} / \mathrm{H}$ & $\mathrm{y} / \mathrm{H}$ \\
\hline$\circ / \Lambda$ & $\circ / \mathrm{N} \Lambda$ & $1 / 01$ & $\circ / 09$ & $r / 0 q$ & $0 / 94$ & $T / T$ & $0 / 91$ & $r / \mu Y$ & $\circ / \mathrm{VA}$ & $\circ / 40$ & $\circ / V 9$ \\
\hline T/ND & $r / q$ & $\Gamma / \Lambda V$ & T/DS & $y / 09$ & $1 / V 0$ & $0 / 91$ & $1 / 04$ & $V / 90$ & $1 / 94$ & $Y / \circ Y$ & T/M \\
\hline$r / \Lambda Y^{r}$ & $9 / \mu \wedge$ & $0 / 9 \wedge$ & $r / 94$ & $\Delta / V q$ & $r / O r$ & $N / \Delta \Lambda$ & I/AY & $\mid r / 4$ & $r / \circ V$ & $r / I r$ & $r / \mu r$ \\
\hline $9 / 99$ & $1 / 11$ & V/AK & G/AY & $9 / 09$ & $4 / 19$ & $10 / 4$ & $T / Y Q D$ & 19 & $\varphi / \Lambda \varphi$ & $\mathrm{V} / \mathrm{A}$ & $Y / T_{G}$ \\
\hline$q / T^{r}$ & $9 / \mathrm{VV}$ & $9 / N r$ & $q / 4$ & $10 / 9$ & $9 / 94$ & $I T / \Lambda$ & $r / \Lambda$ & $T Y / D$ & $9 / 99$ & $11 / 9$ & $\Delta / \Gamma^{\omega}$ \\
\hline $14 / \pi$ & $9 / 91$ & $\mid r / 4$ & $10 / \mu$ & $10 / 1$ & $N / I T$ & 10 & $r / \varphi v$ & $m 1 / 9$ & $\mathrm{~V} / \mathrm{OV}$ & 11 & $0 / 1$ \\
\hline $1 V / 9$ & $1 / \wedge 9$ & $10 / 1$ & $10 / 4$ & $r Y / Y$ & $N / T_{q}$ & $I V / 0$ & $Y / 4 T$ & «N/D & $V / Y^{\alpha}$ & $r M / V$ & $\varphi / \mu$ \\
\hline$r Y / D$ & $1 / 90$ & ro & $N / \Delta \varphi$ & $r \Lambda / 4$ & $9 / 79$ & $r \circ / D$ & $\Delta / V V$ & $Y Y / \Lambda$ & $9 / 49$ & $Y Y / 9$ & T/MY \\
\hline$r G / T$ & $9 / 09$ & $r \mu / 4$ & $V / 4$ & 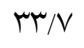 & $r / 9 r$ & ro & $0 / \mu 1$ & $x y / 9$ & $\Delta / \pi \Delta$ & $r \in / 4$ & $1 / T \wedge$ \\
\hline$r \Lambda / 9$ & $4 / 99$ & re/A & $Q / \Delta Q$ & $\mu \mu / \Lambda$ & $1 / \pi$ & YN/G & $\varphi / r \Delta$ & $\varphi \& / 1$ & $r / \Delta$ & $r V / T^{C}$ & 0109 \\
\hline
\end{tabular}

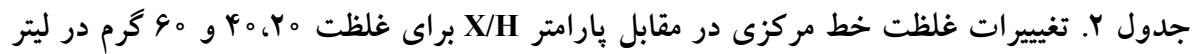

\begin{tabular}{|c|c|c|c|c|c|c|c|c|c|c|c|}
\hline \multicolumn{2}{|c|}{$C_{0}=r \circ g / 1$} & \multicolumn{2}{|c|}{$C_{0}=r \circ g / 1$} & \multicolumn{2}{|c|}{$\mathrm{C}_{0}=9 \circ \mathrm{g} / 1$} & \multicolumn{2}{|c|}{$C_{0}=r \circ g / 1$} & \multicolumn{2}{|c|}{$C_{0}=r \circ g / 1$} & \multicolumn{2}{|c|}{$\mathrm{C}_{0}=9 \circ \mathrm{g} / 1$} \\
\hline $\mathrm{x} / \mathrm{H}$ & $\mathrm{C}_{\mathrm{m}} / \mathrm{C}$ 。 & $\mathrm{x} / \mathrm{H}$ & $\mathrm{C}_{\mathrm{m}} / \mathrm{C}$ 。 & $\mathrm{x} / \mathrm{H}$ & $\mathrm{C}_{\mathrm{m}} / \mathrm{C}_{\text {。 }}$ & $\mathrm{x} / \mathrm{H}$ & $\mathrm{C}_{\mathrm{m}} / \mathrm{C}$ 。 & $\mathrm{x} / \mathrm{H}$ & $\mathrm{C}_{\mathrm{m}} / \mathrm{C}$ 。 & $\mathrm{x} / \mathrm{H}$ & $\mathrm{C}_{\mathrm{m}} / \mathrm{C}$ 。 \\
\hline س & .191 & אות & $0 / 94$ & ת & r r & $\Delta S / T \Delta$ & $0 / 4 r$ & $\Delta \varphi / T \Delta$ & $0 / 14$ & $\Delta \varphi / T \Delta$ & $0 / T V$ \\
\hline To & $0 / 94$ & TQ & $\circ / 40$ & ro & $\circ / T \Delta$ & $G \wedge / \vee \Delta$ & $\circ / \notin V$ & $9 \wedge / \vee D$ & O/Y & $G \wedge / \vee \Delta$ & $\circ / Y \Lambda$ \\
\hline $41 / 94$ & $\circ / \mu V$ & $41 / 99$ & 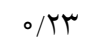 & $41 / 94$ &.$/ \mathrm{V}$ & $\Lambda I / T \Delta$ & $\circ / 4 V$ & $\Lambda 1 / T \Delta$ &.$/ \mathrm{V}$ & $\Lambda 1 / T \Delta$ & $0 / Y \Lambda$ \\
\hline$\Delta \Lambda / T \mu$ &.$/ \Delta r$ & & $\circ / 1 V$ & $0 \Lambda / \mu T$ & $0 / 14$ & $q \pi / v \Delta$ & $\circ / 4 V$ & $q r / v \Delta$ & $\circ / \mathrm{V}$ & $q \mu / v \Delta$ & $0 / 49$ \\
\hline VQ & $0 / 4 Q$ & VQ & . & VQ & $0 / 14$ & $109 / \pi 0$ & .40 & $109 / \pi 0$ & $0 / 19$ & $109 / \pi 0$ & $0 / 49$ \\
\hline $91 / 99$ & $0 / 4 \wedge$ & $91 / 99$ & $0 / 14$ & $91 / 99$ & $0 / 14$ & $Y / \Delta Y$ &.$/ 90$ & $Y / Q T$ &.$/ D Y$ & $Y / \Delta Y$ &.$/ D T^{k}$ \\
\hline 1. & $0 / \mu$ & س & $\circ / Y^{k}$ & س & $0 / 14$ & $1 \pi / 9 r$ &.$/ 09$ & $1 r / 9 r$ & $\circ / \mu_{0}$ & Ir/ar & ./QT \\
\hline ITO & $0 / \pi 1$ & ITO & O/Y & $1 T \Delta$ & $0 / 19$ & Tr/VT & $\circ / D Y$ & TYNY & ס & TY/VY & $0 / 49$ \\
\hline $141 / 94$ & $0 / \pi 1$ & $141 / 99$ & $\circ / \mathrm{V}$ & $141 / 99$ & $0 / 19$ & MI/AI & $\circ / \uparrow \wedge$ & $r \mid / N$ & OMT & MI/NI & $0 / 49$ \\
\hline 101/R & $0 / \mu 1$ & س & $0 / 14$ & س & $0 / T_{1}$ & $4 \circ / 9 \circ$ & $0 / 49$ & $\varphi \circ / 9 \circ$ & س & $4 \circ / 90$ & $0 /$ ky \\
\hline IVO & $0 / \pi 1$ & IVO & $\circ / \wedge$ & IVD & $0 / T_{1}$ & Q. &.$/ 01$ & Q. & $\circ M K$ & Q. & OMY \\
\hline$G / T \Delta$ & $0 / 90$ & $G / T \Delta$ &.$/ 09$ & $G / T \Delta$ & o/VG & $09 / \circ 9$ &.$/ 01$ & $09 / \circ 9$ & ORT & $09 / 09$ & DTr \\
\hline IN/VQ & - /QT & $1 \wedge / \vee D$ & $\circ / \mu \wedge$ & IN/VQ & $\circ / \Delta \Delta$ & $9 \wedge / 1 \wedge$ & $\circ / \Delta Y$ & $9 \wedge / 1 \Lambda$ & $\circ / \mu_{0}$ & $9 \wedge / 1 \Lambda$ & $0 / T^{\prime}$ \\
\hline$M / / T \Delta$ & תr/o & $T I / T Q$ & $\circ / T V$ & $M T / T \Delta$ & $0 / \pi q$ & $V V / T V$ & $0 / 4 q$ & $V V / T V$ & o/r & $V V / T V$ & $0 / T V$ \\
\hline$\Psi \Psi / V Q$ & $0 / \mathcal{F}_{0}$ & $\mu \mathrm{N} / \mathrm{VQ}$ & o/rT & $\mu \mathrm{r} / \mathrm{VQ}$ & $\circ / \mu_{0}$ & $\Lambda G / \mu q$ & $\circ / \omega$ & $19 / \pi q$ & $0 / 4 q$ & $19 / \mu q$ & \\
\hline
\end{tabular}

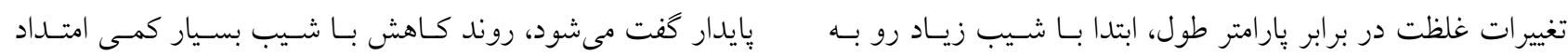

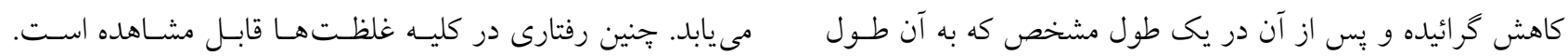




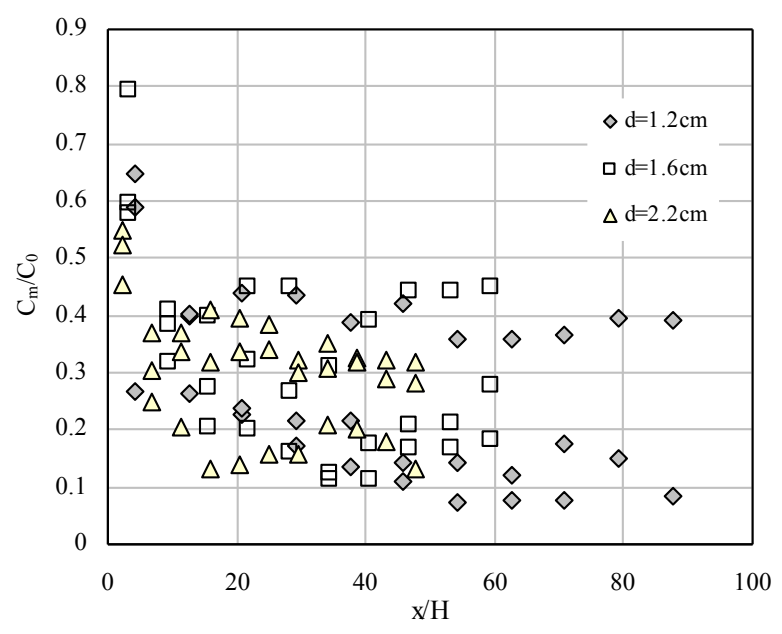

(ب)

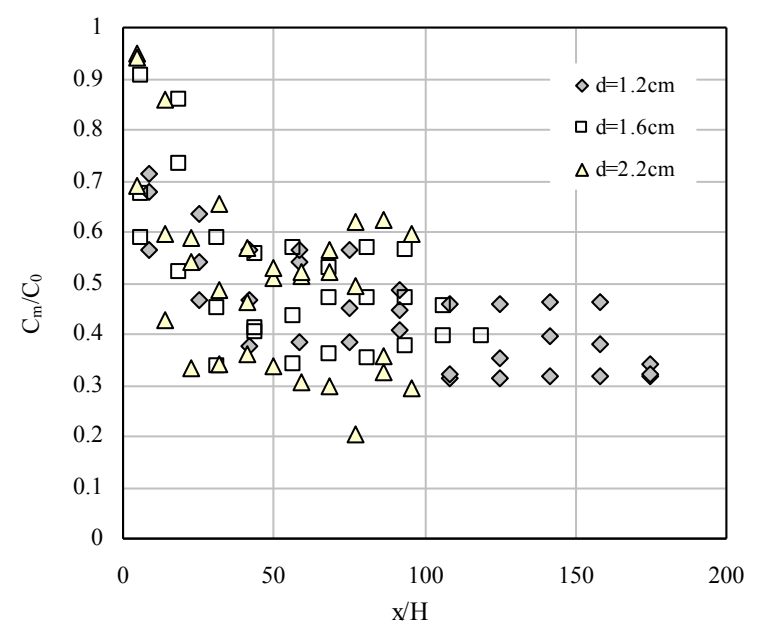

(الف)

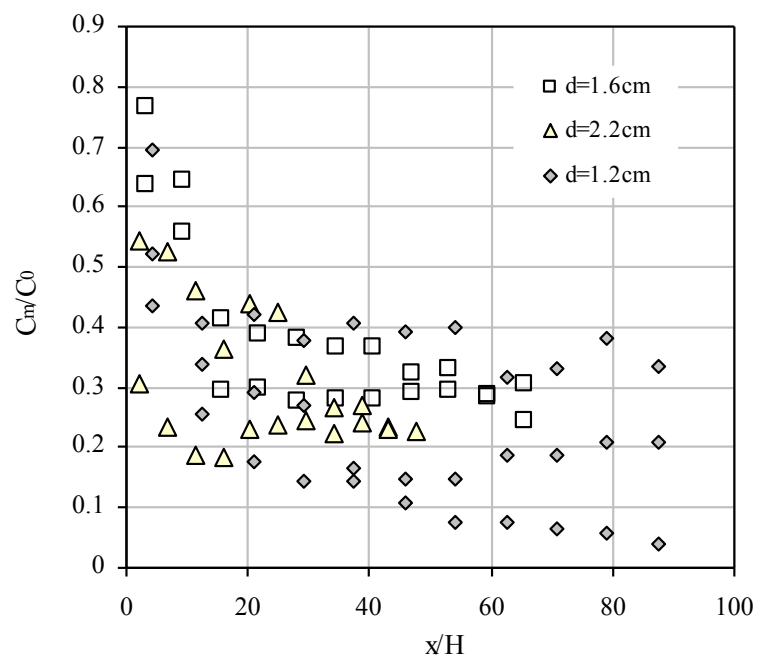

(ج)

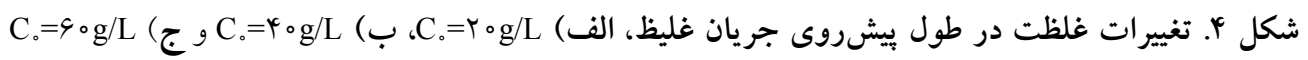

تأثير جت محيط بيرامون تداخل كمترى با فلاكس جـت برقـرار

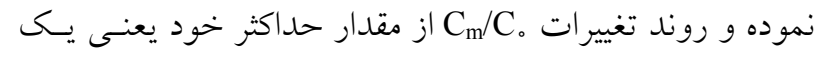

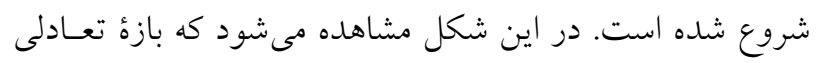

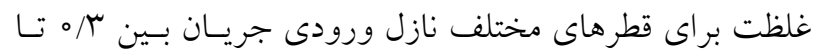

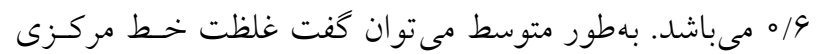

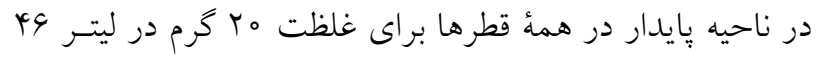

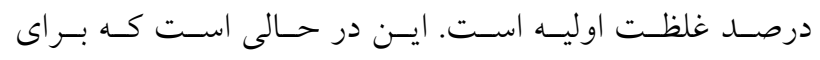

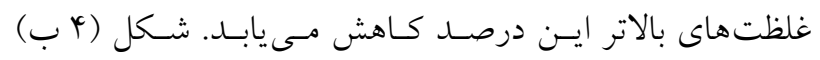

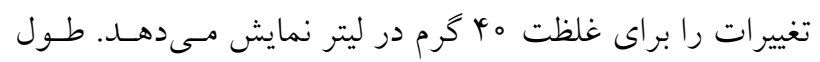

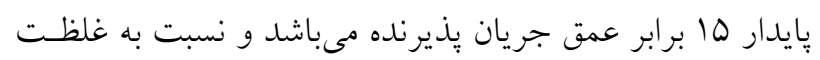

علت اين رفتار را مى توان به ناحيـهُ تحــت تـأثير بـين جــت و

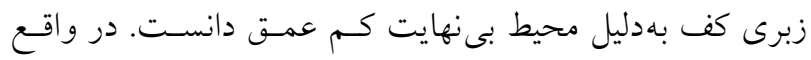
اندركنش بين جريان خروجى جت و محيط يذيرنده بسى نهايـت

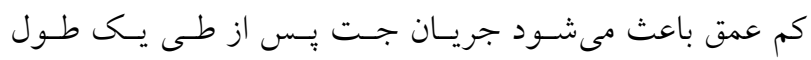

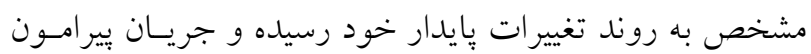

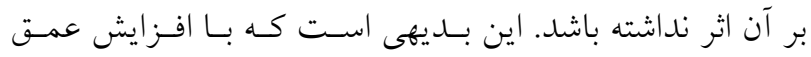

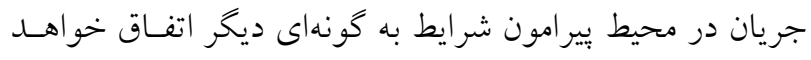

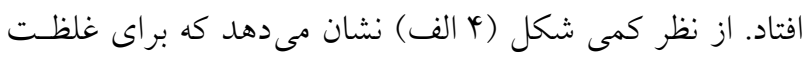

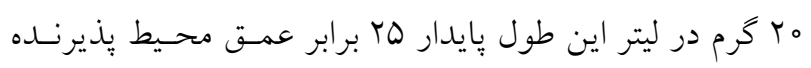

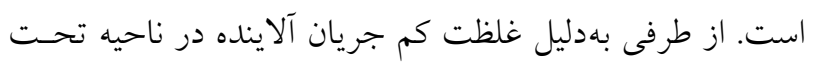




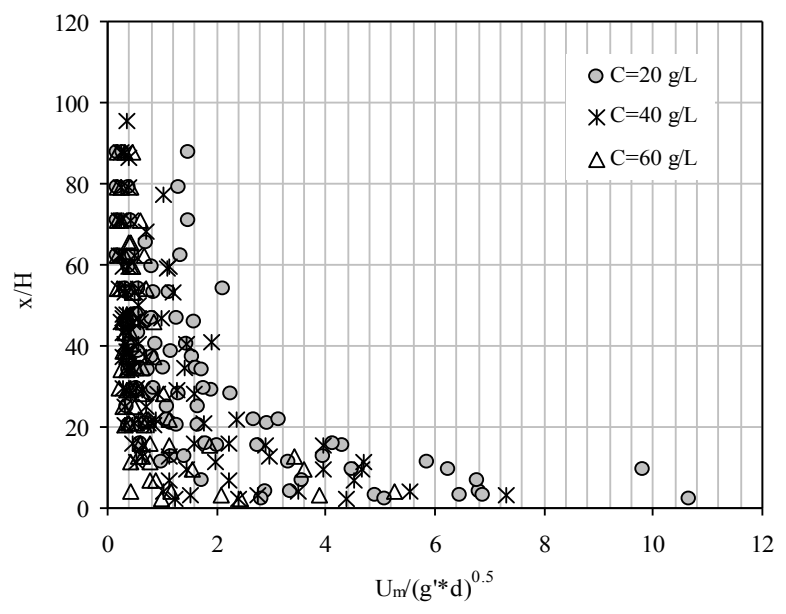

شكل 9. بارامتر اينرسى جريان در طول بيشروى فلاكس جريان جت

در طول x=110سبت به محل نازل بررسى شده است. لازم

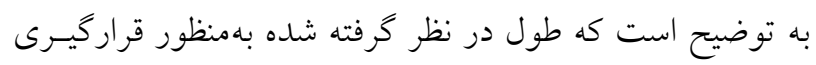

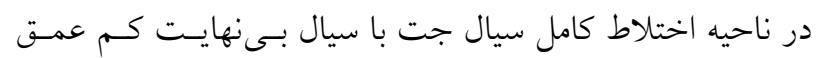

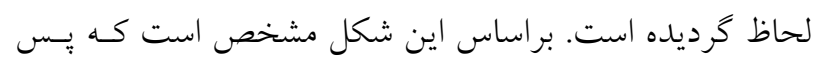

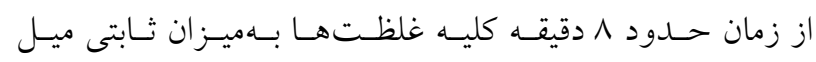

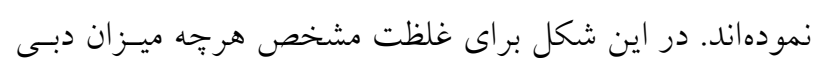

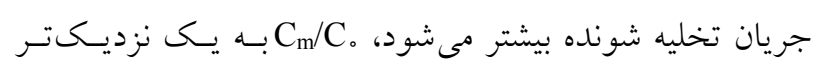

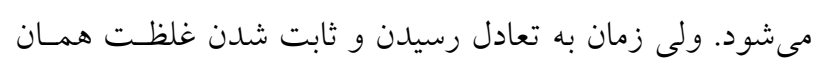
حدود ^ دقيقه است. در مجموع در غلظتهاى وبايين تـر مقــادير

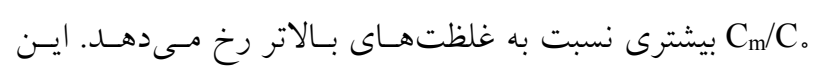

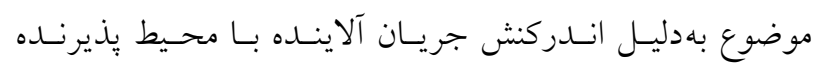

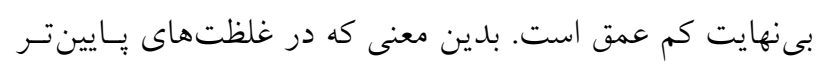

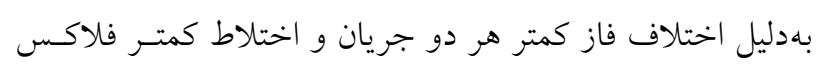

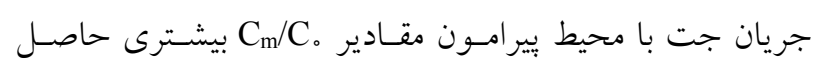

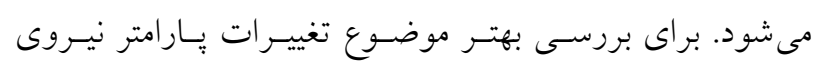

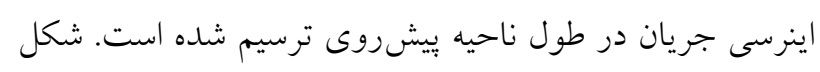

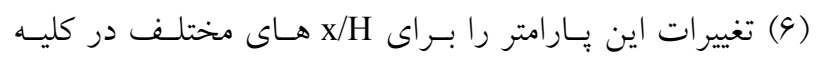
آزمايشهاى تحقيق حاضر نمايش مى دهد.

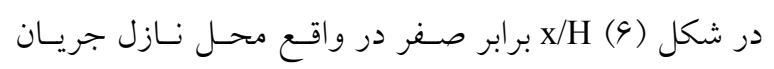

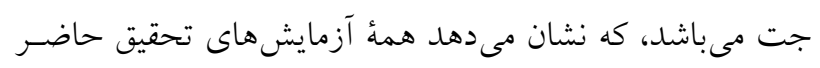

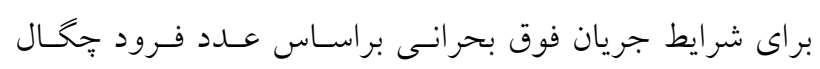

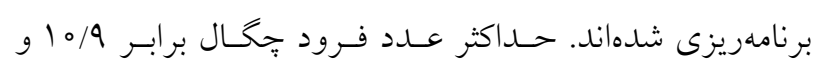

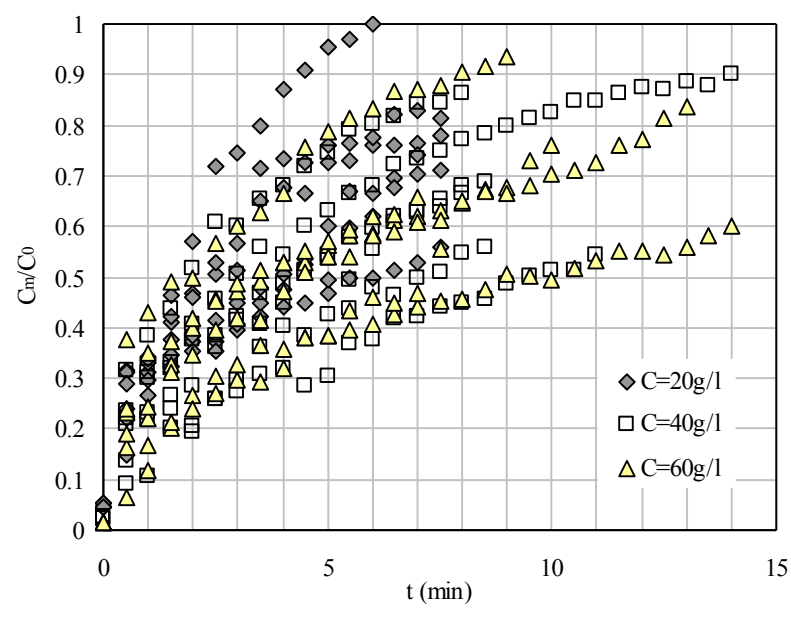

شكل هـ تغييرات غلظت خط مركزى نسبت به زمان براى

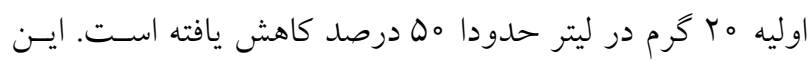

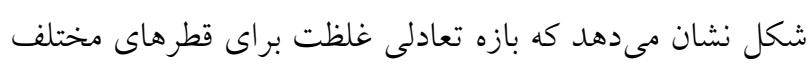

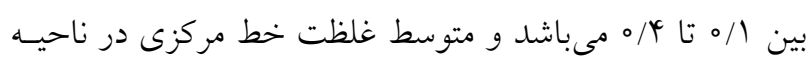

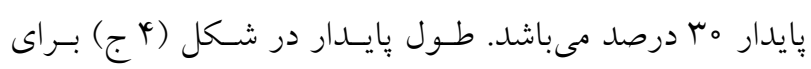

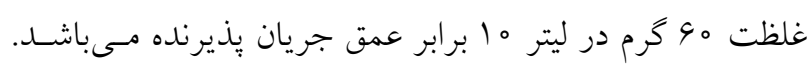

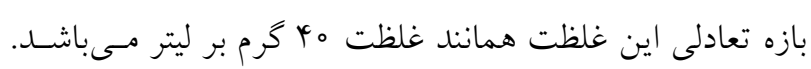

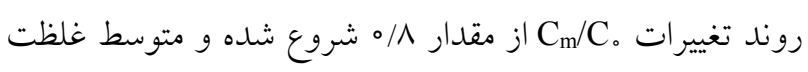

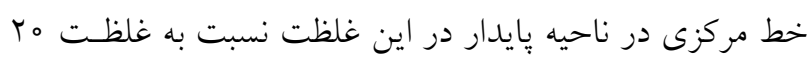

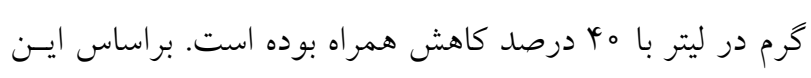

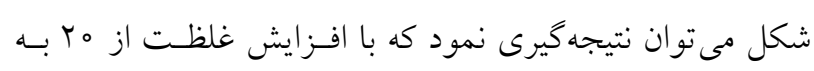

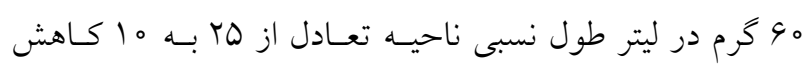

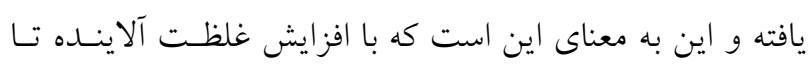

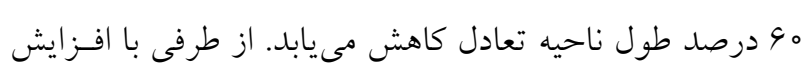

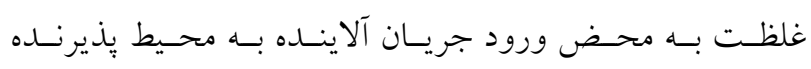

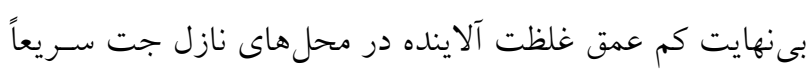

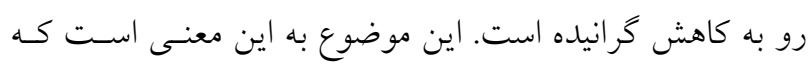

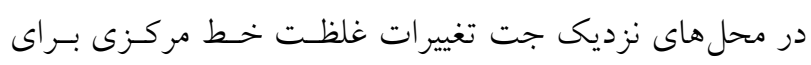

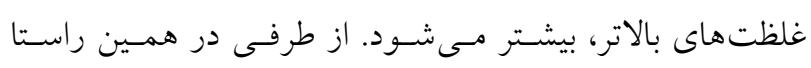

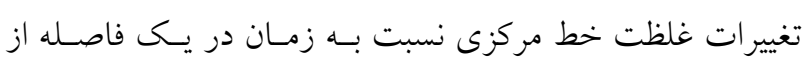

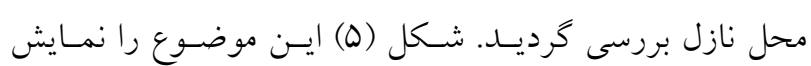
مى دهل. براساس شكل (ه) روند تغييرات زمانى غلظت خط مركـزى 


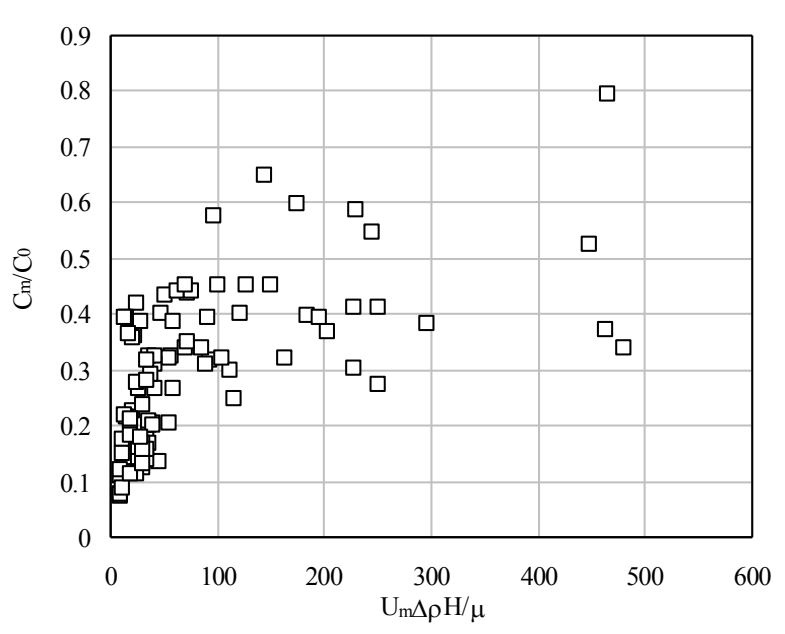

(ب)

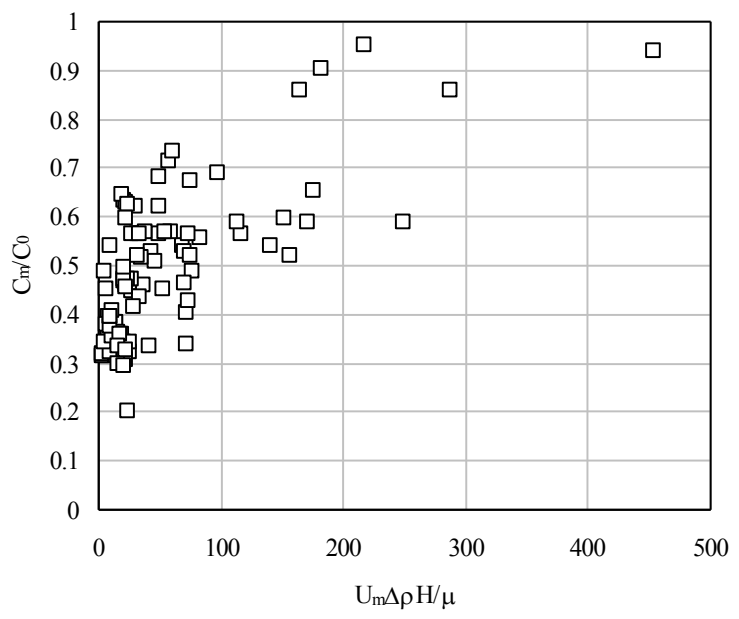

(الف)

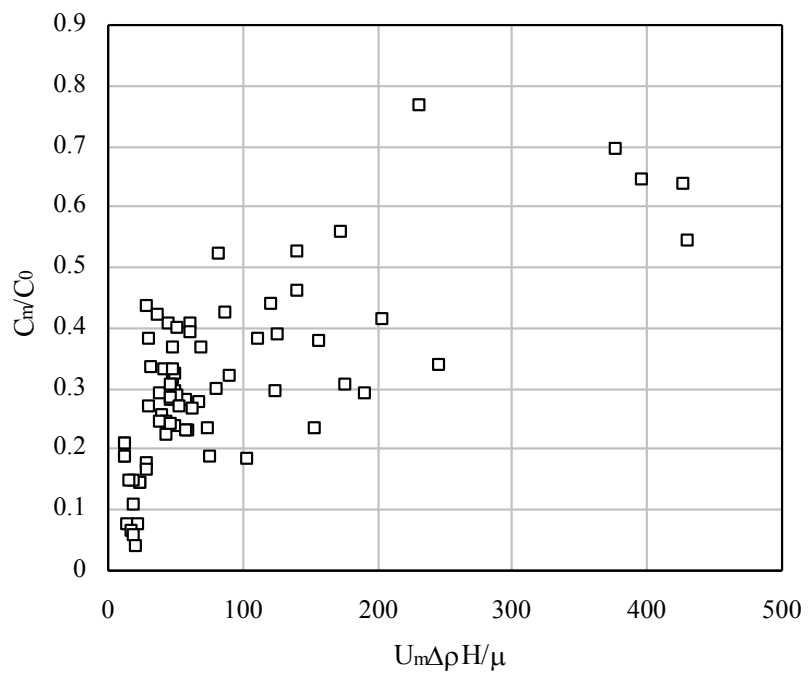

(ج)

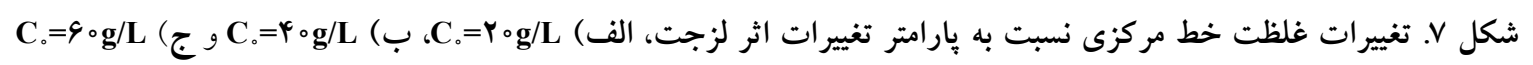

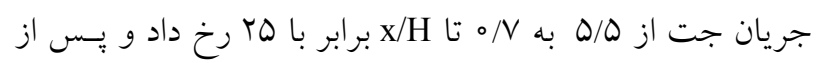

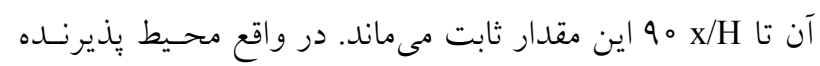

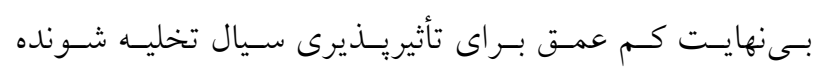

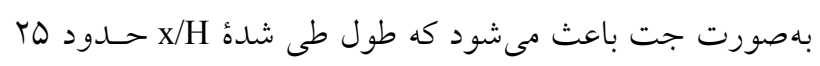

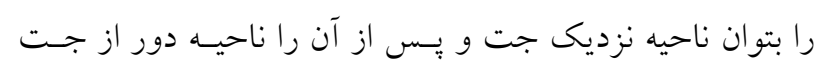

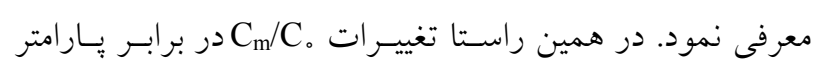
تغييرات اثر لزجت در شكل (V) ترسيم شده است.

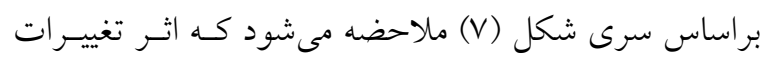

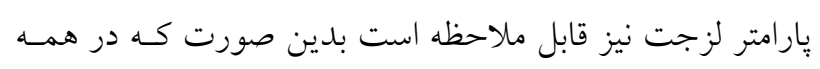

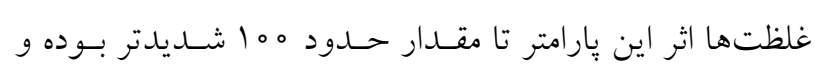

مربوط به آزمايش با غلظت هب كرم در ليتر اسـت و در غلظـت

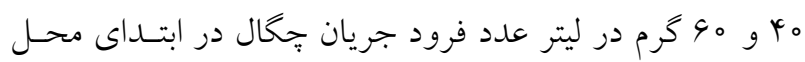
تخليه بهترتيب V/ه و ه/ه مى باشد. مطابق با ايسن شـكل ناحيـه

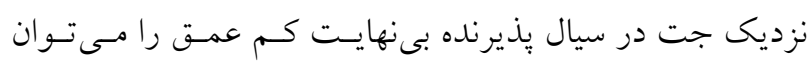

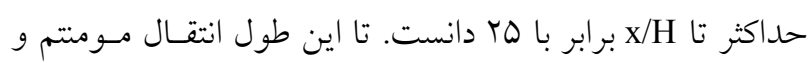

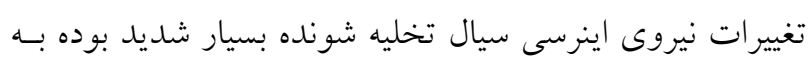

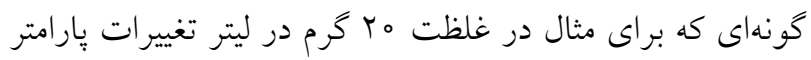

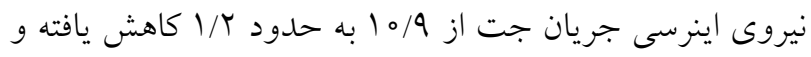

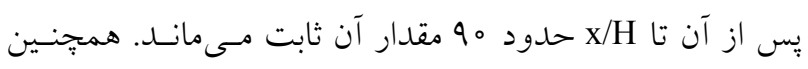

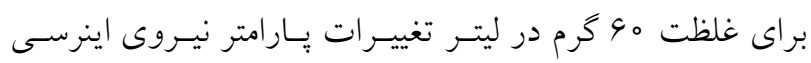




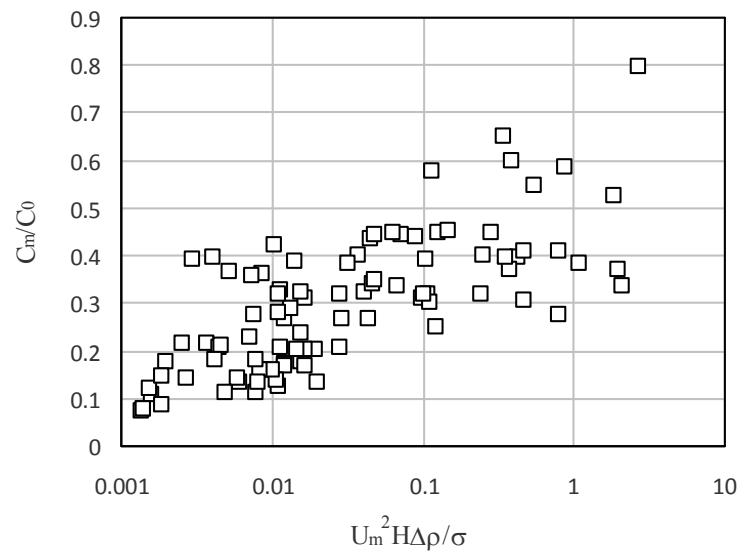

(ب)

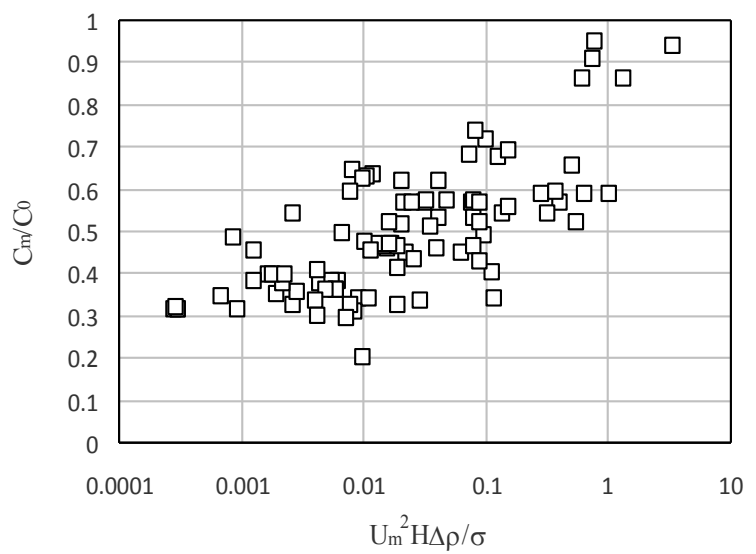

(الف)

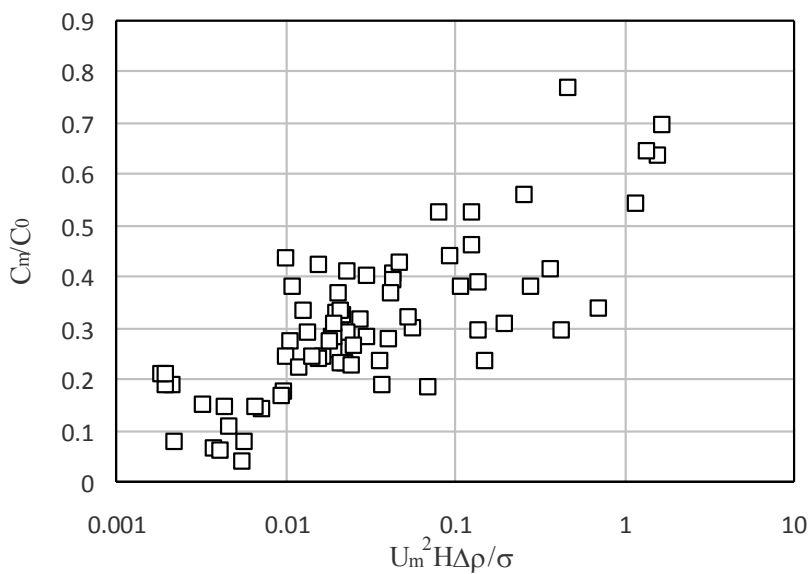

(ج)

شكل ^ـ تغييرات غلظت خط مركزى نسبت به بارامتر تغييرات اثر كشش سطحى، الف)

نازل تا انتهاى بيشروى وجود دارد. در واقع عمق بىنهايست كـمـ

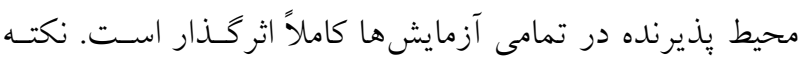

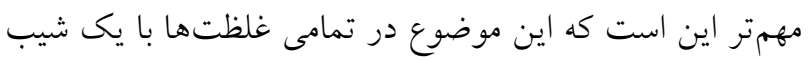

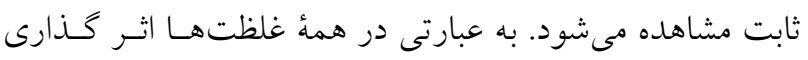

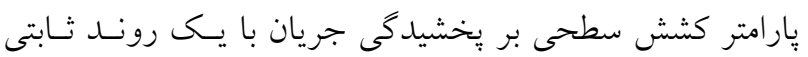

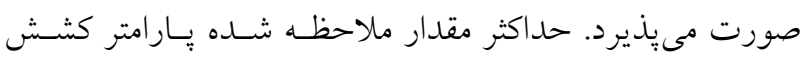

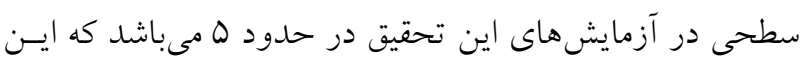

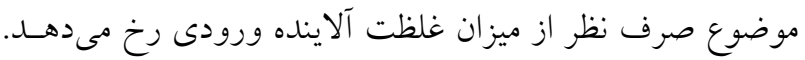
در واقع در تمام غلظتها يٌ از طول ناحيه پِايدار و استهلاك انرزى ناحيه جت مقدار بارامتر كشش سـطحى بـه هـ مسرســ. ولى بديهى است كه مقدار كمينهُ آن تابعى از ميزان غلظت اوليـه ورودى بوده و با افزايش غلظـت اوليـه حـــاقل مقــدار بـارامتر

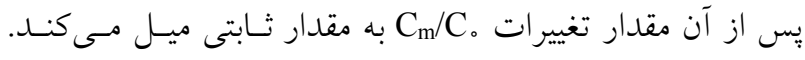

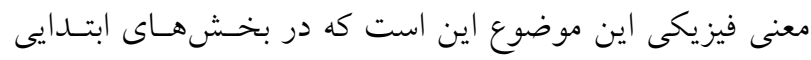

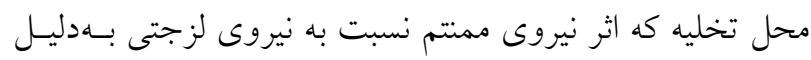

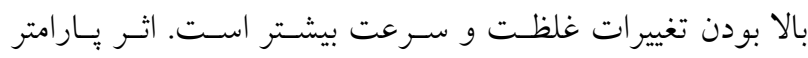

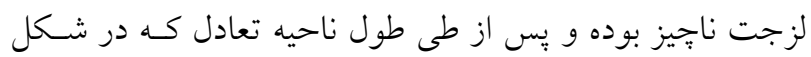

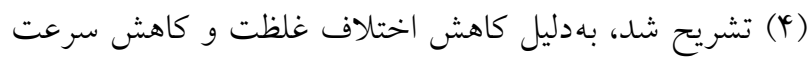

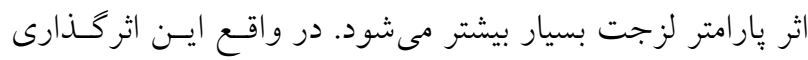

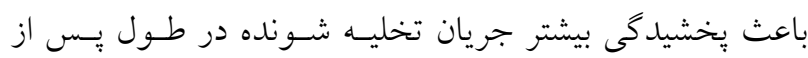

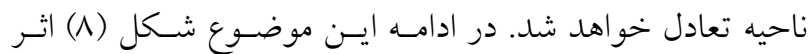
كذار كشش سطحى را نمايش مىدهد. مطابق با سرى شكل (N) مشاهده مسى شـود كـه اثـر پـاراتر كشش سطحى همواره در كليه مراحل تخليـه از ابتـداى محـل 

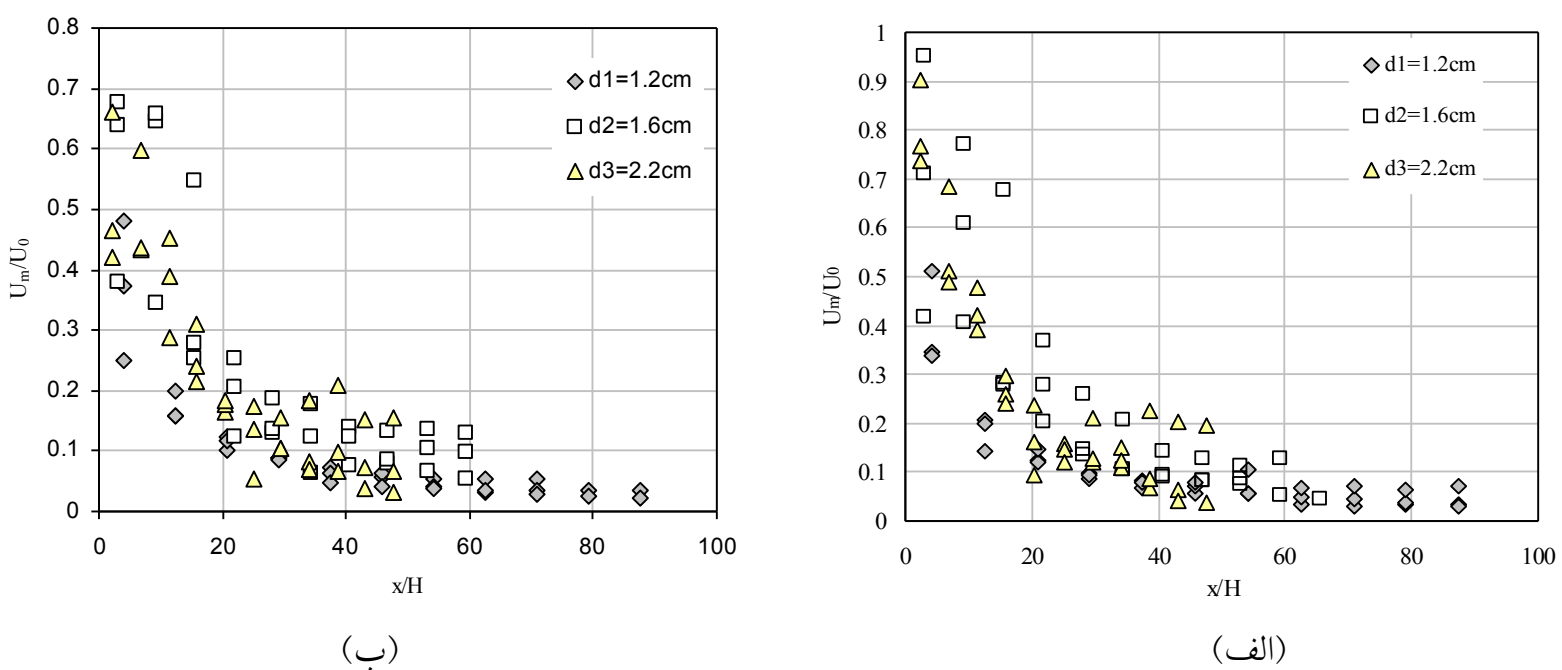

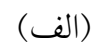

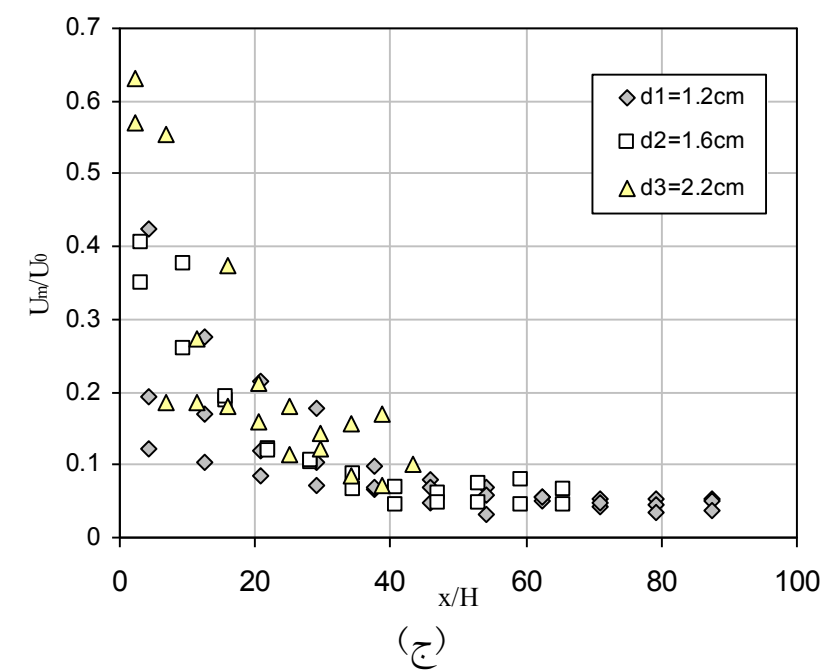

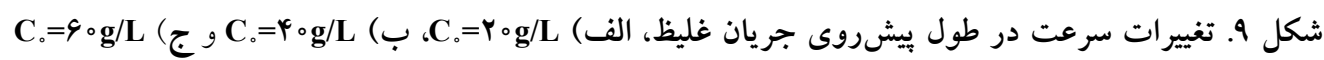

شكل (الف)، (ب) و (ج) شـكل (9) ملاحظـه مسى شـود كـه در

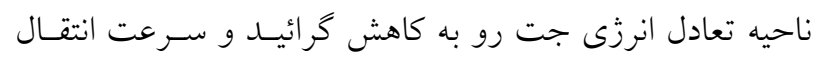

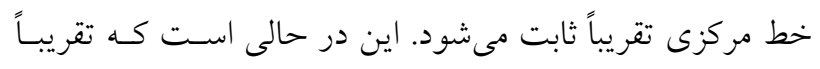

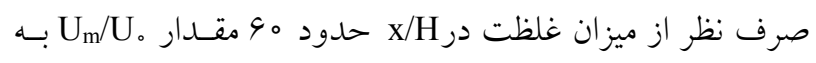

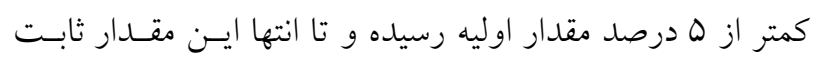

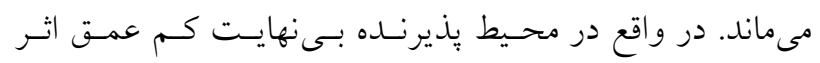

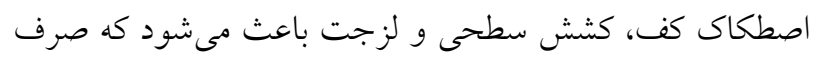

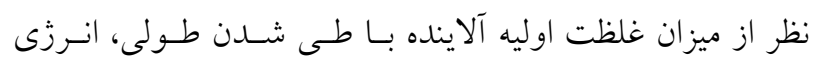

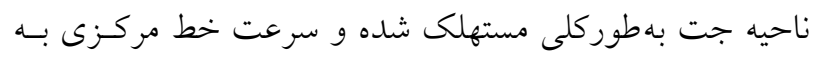

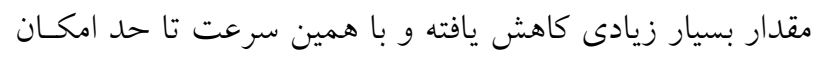

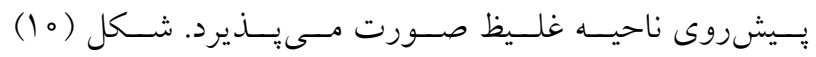

كشش سطحى افزايش مى يابـــ. درادامـهـ بـــاى بررسى شـرايط

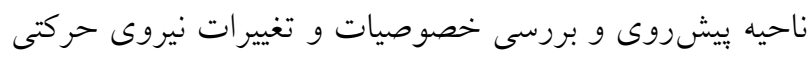

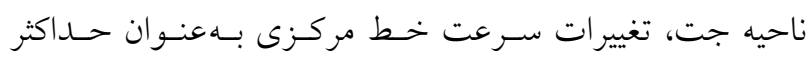
سرعت در هر مقطع عرضى از محل نازل جت نسبت بـه طسول نسبى x/H در شكل (9) ترسيم شده است.

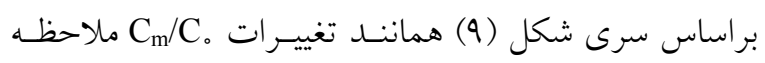

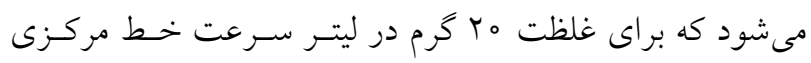

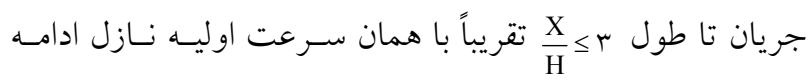
يافته و يّ از آن رو به كاهش مى كرايد. اين درحالى اسـت كـهـ با افزايش غلظـت بـه محضـ ورود جريـان آلاينـده بـه محسيط

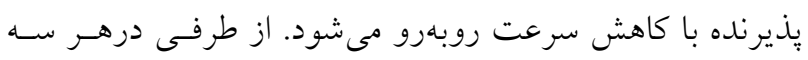



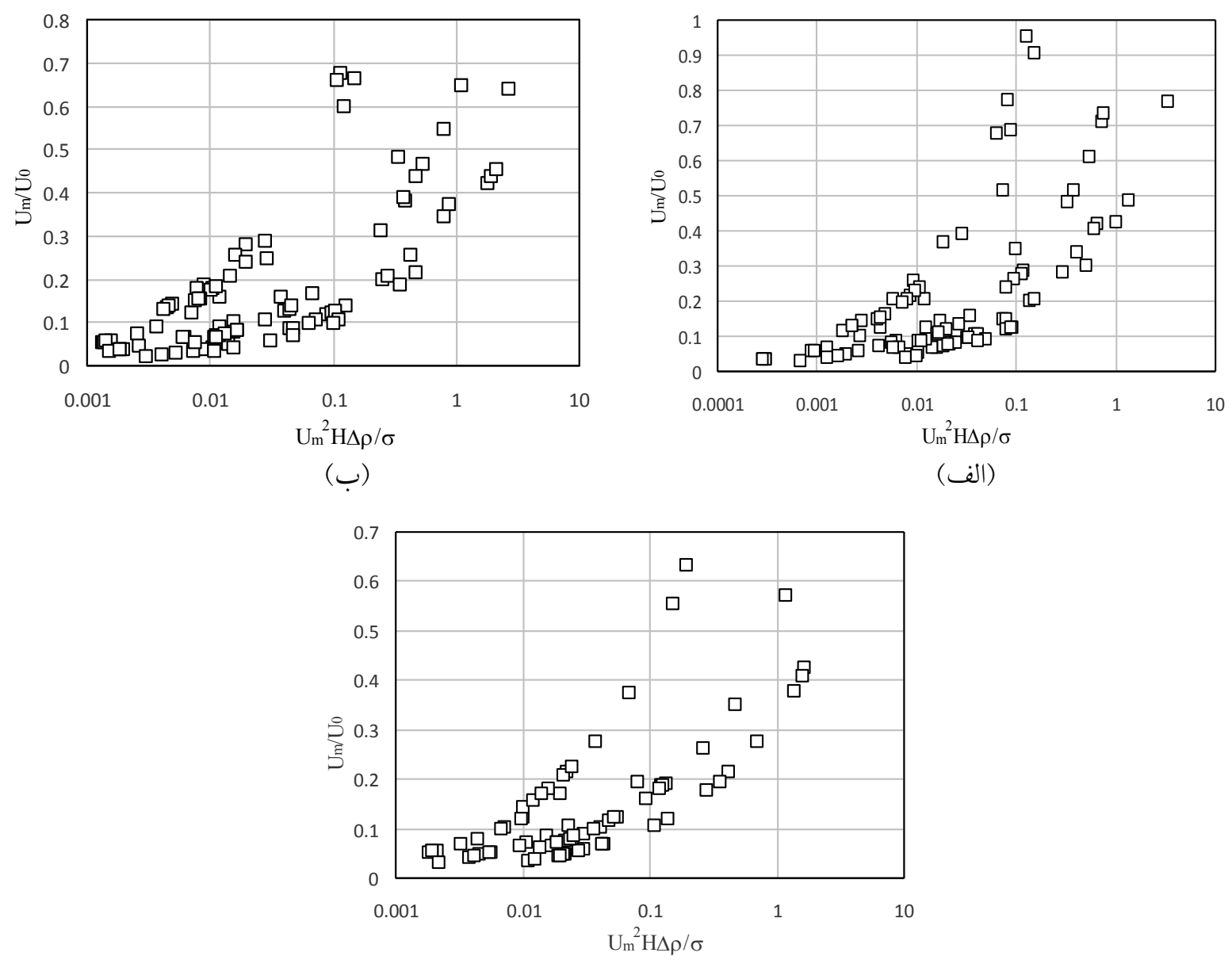

(ج)

$C_{0}=9 \circ g / L($ و ج C C

مقادير كمتر از / / ملاحظه مىشود كه اثر كشش سطحى نسبت

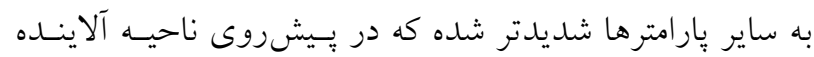

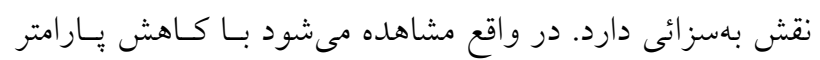

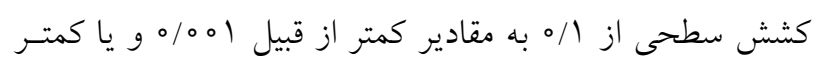

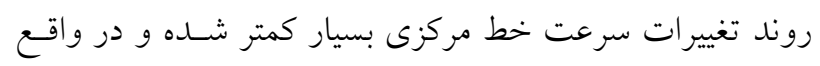

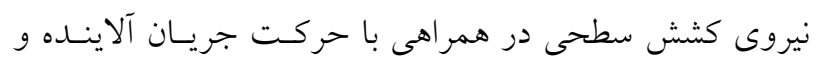

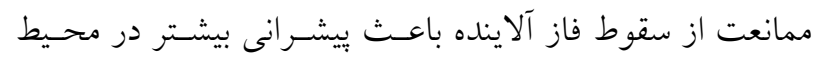

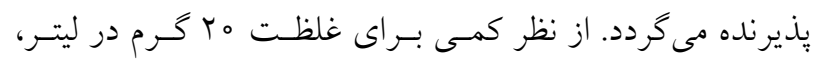

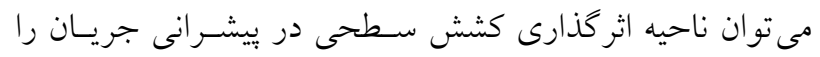

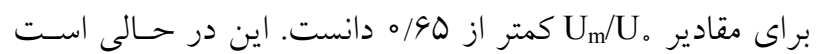

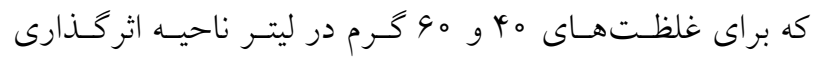

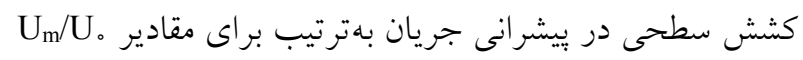

اثر پارامتر كشش سطحى را بر تغييـرات سـرعت خـط مركـزى نمايش مىدهد.

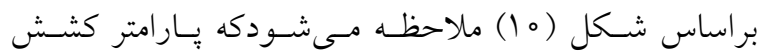
سطحى بر روند تغييرات سرعت به جه صورتى تأثير كذار است.

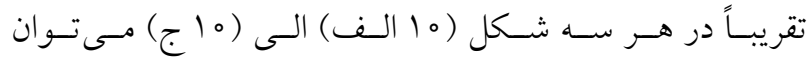

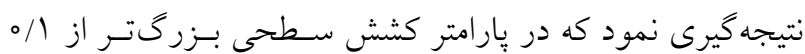

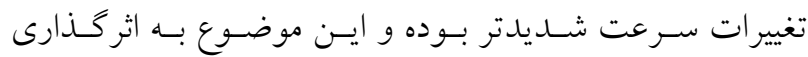

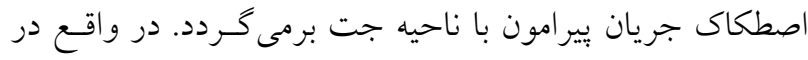

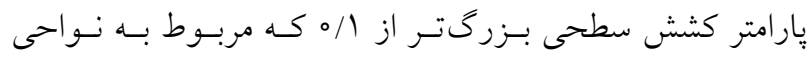

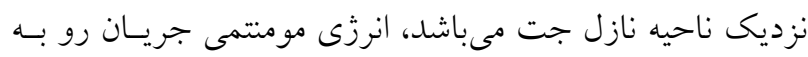

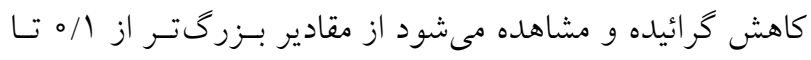

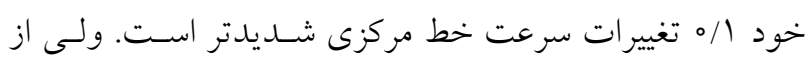


محاسباتى كه در استخراج رابطه (9) نقشى نداشـتند استخراج

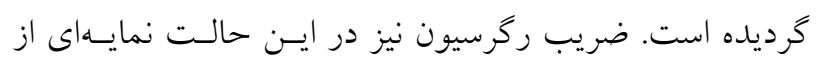

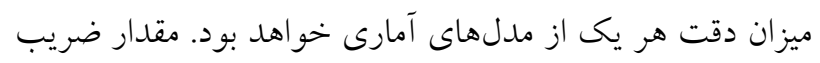

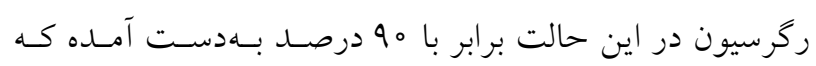

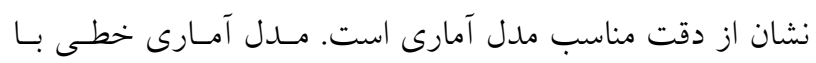

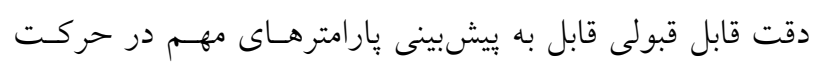

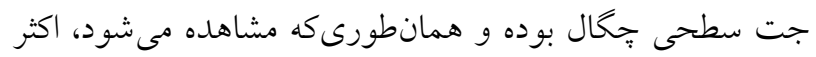

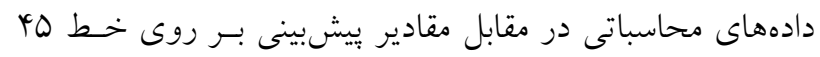
درجه واقع شدهاند.

\section{مقايسه با تحقيقات كذشته}

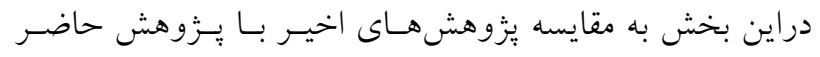

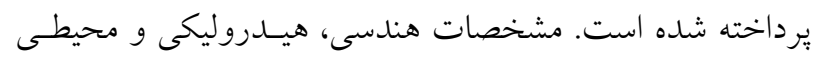

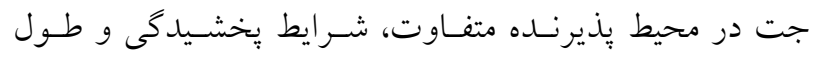

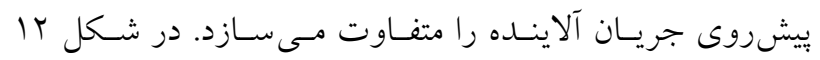

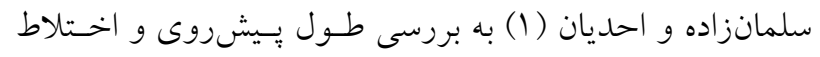

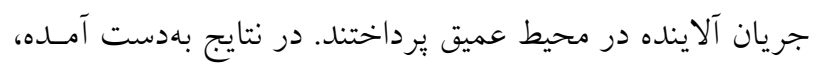

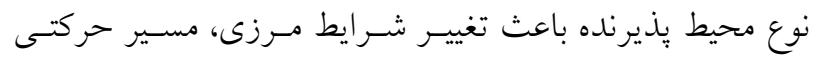

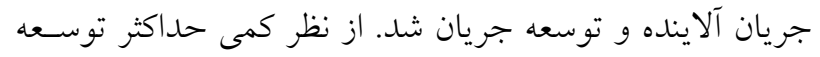

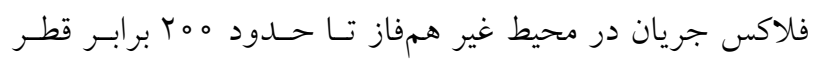

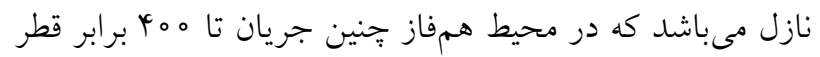

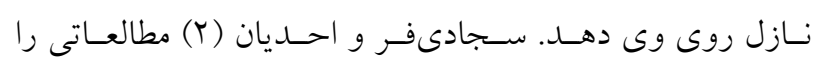

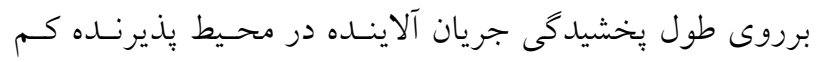

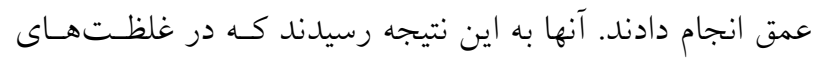

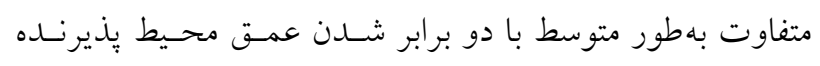
طول بيشرونده هسته جت بهترتيب مب درصد افزايش مى ميابـد.

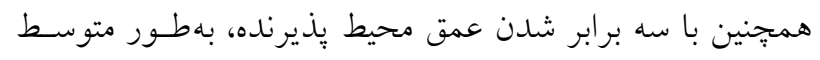

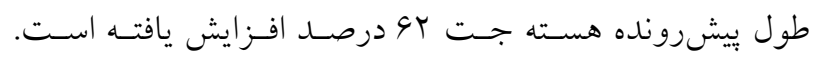

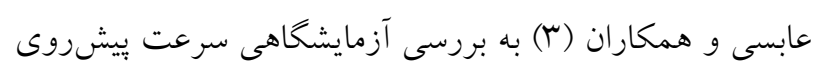

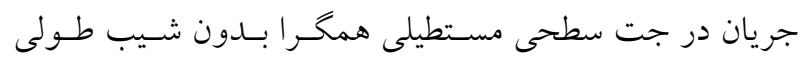

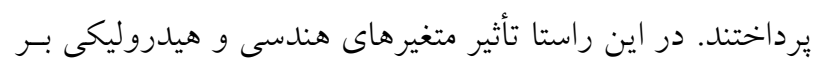
سرعت ييش روى جريان مورد بررسى قرار كرفت. مطابق نتسايج

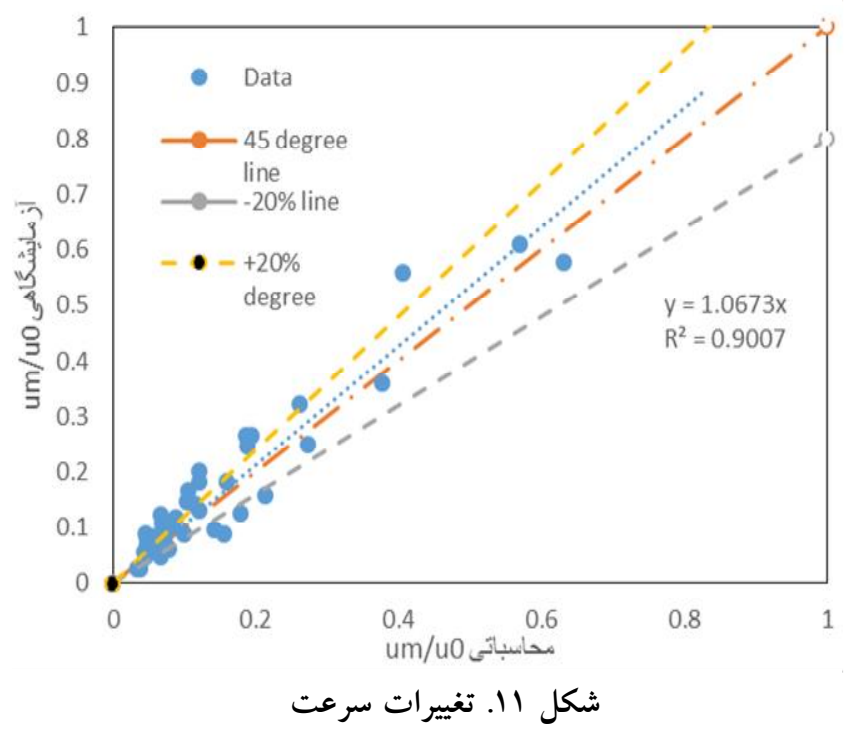

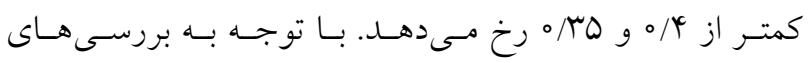

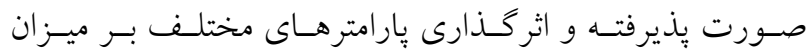

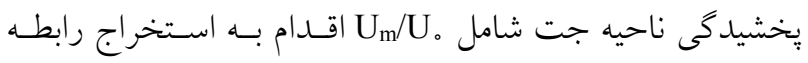

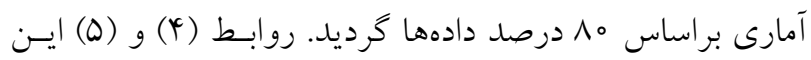

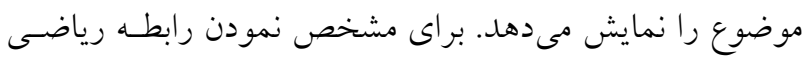

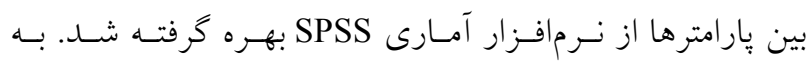
كونهاى كه روشهاى مختلف خطى و غير خطى مـورد آزمسون

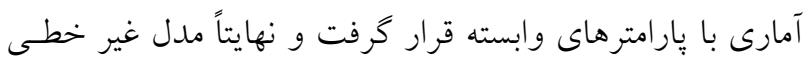

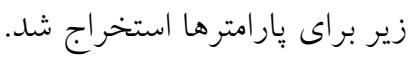

$\frac{U_{m}}{U_{o}}=f\left(\frac{C_{m}}{C_{o}}, \frac{X}{H}, F_{j}\right)$

$\frac{U_{m}}{U_{0}}=-0 / \uparrow v\left(\frac{C_{m}}{C_{0}}\right)+\left(\frac{X}{H}\right)^{-0 / r q 1}+\left(F_{j}\right)^{\circ / \% \uparrow \wedge}-1 / 1 r \Delta$

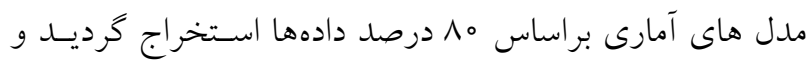

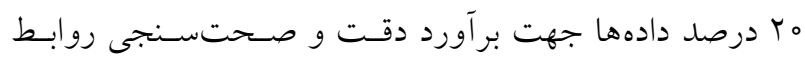

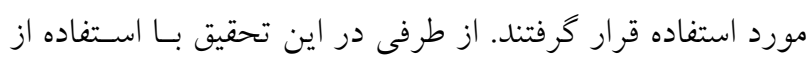

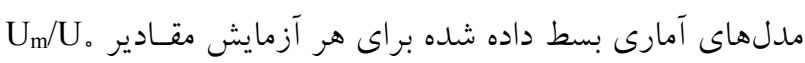

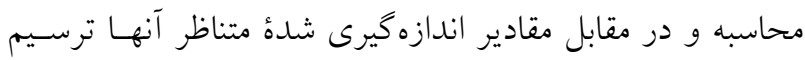

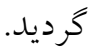
شكل (ما) تغيير ات مقــادير انــازهذيـرى شـــه سـرعت در

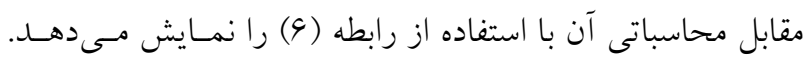

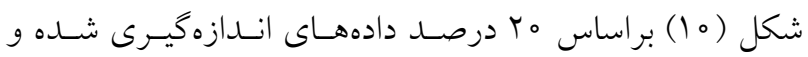




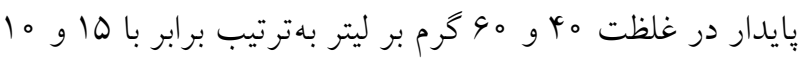

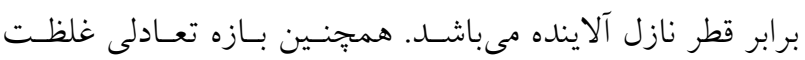
براى هر دو غلظت اوليه ياد شده بين //ه تا \&/ه مىباشد. نتايج نشان داد كه در طولى بِ از طول بِايدار تغييرات زمانى غلظت در محيط يذيرنده بى نهايت كم عمق به گونهاى است كه بـس از طى مدت زمان حدود ^ دقيقه غلظت به مقادير حسـدود غلظـت

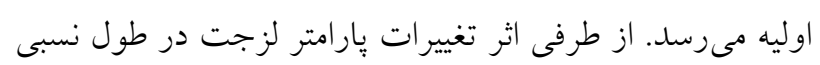
طى شده بدينصورت است كه در همه غلظتها اثر اين بـارامتر

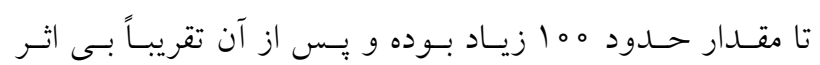
مىشود. از طرفى نتايج نشان داد كه اثر يـارامتر كشـش سـطحى

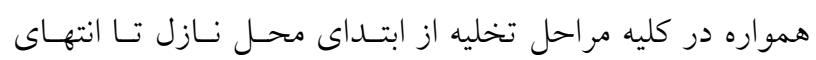
بيشروى وجود دارد. اين موضوع به اين معنى است كه در همسـ غلظت ها اثر گذارى بارامتر كشش سطحى بر بخشـيدگى جريـان

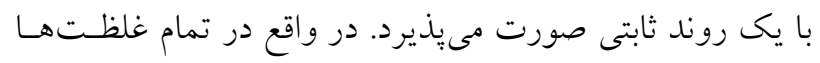
بس از طول ناحيه يُايدار و استهلاكى انرزى ناحيـه جـت مقـدار يار امتر كشش سطحى به ه مىرسد. ولى مقدار حداقل آن تابعى

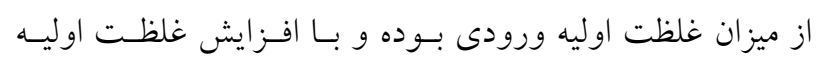
حداقل مقدار يارامتر كشش سطحى افزايش مسىيابـــ. از طرفى براساس نتايج تغييرات سرعت خط مركـزى در مقـادير بـارامتر كشش سطحى بزرگتر از // تغييرات سرعت زيادتر مىباشـــ.

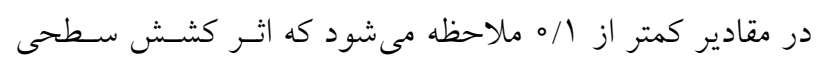

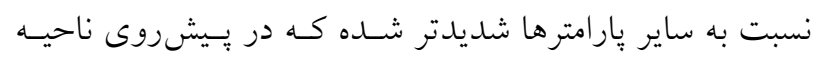

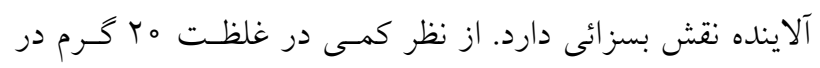

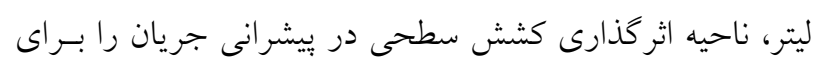
مقادير oUm/U كمتر از 190/ دانست. ايسن در حسالى اسـت كـه

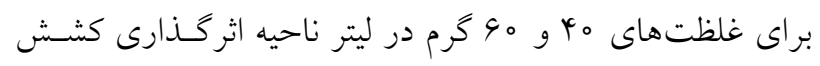

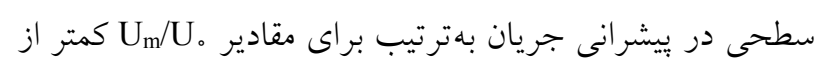

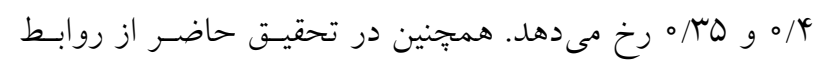

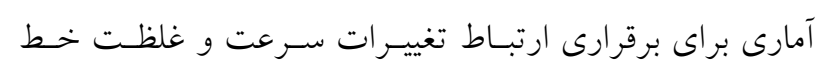
مركزى استفاده شد.

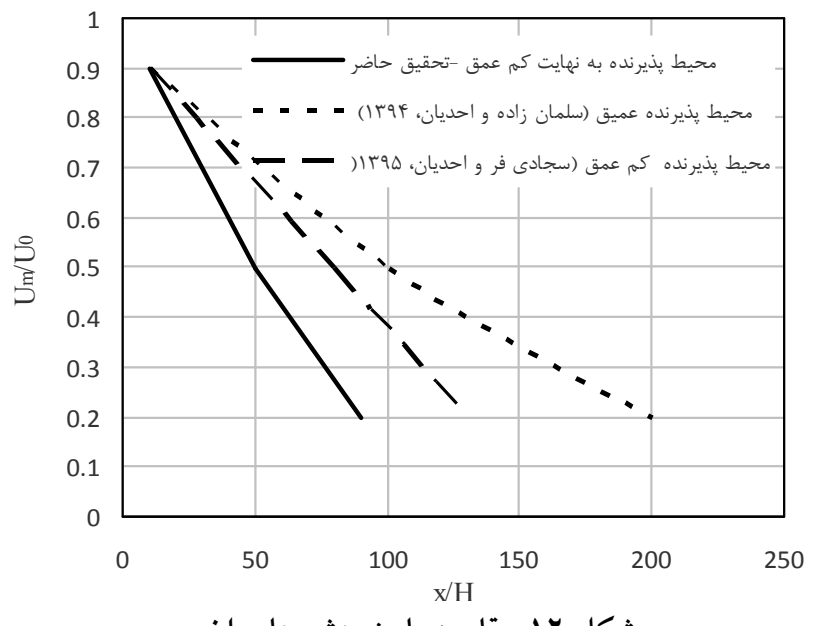

شكل r Ir. مقايسه با بُزوهش هاى اخير

بهدست آمله، در حالت آزاد و خروجى سطحى در عمق يكسان طول بيشرونده بيشترى را نسبت به حالت مسـتغرق دارنـــ. در

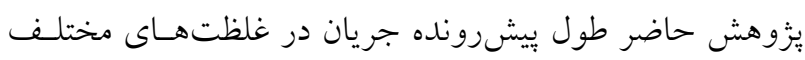

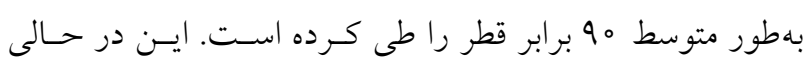
است كه در غلظتهاى بيشتر طول بيشرونده كمترى نسبت بـهـ غلظت هاى كمتر است. شـكل ( ا (1) سـرعت يـيشروى جريـان آلاينده در محيطهاى بذيرنده متفاوت نسبت به طول بـيشروى را نمايش مى ندهد.

\section{نتيجه گيرى}

براساس آزمايشهاى انجام شده در خصوص تخليه جريان جت سطحى در محيط يذيرنسده بسىنهايست كـم عمـق نتـايج مهمى استخراج گرديد. بـراى ايسن منظـور ناحيـه يخشيدكى جريـان آلاينده باهصورت مختصاتى برداشت شـد و تغييـرات غلظـت و و سرعت خط مركزى در ناحيه فلاكس طولى مورد بررسسى واقع بـع شد. نتايج نشان داد كه اندركنش جريان جت و محسيط يذيرنـده

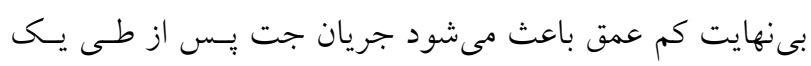
طول مشخص به روند تغييرات پايدار خود برسـد. نتـايج نشـان

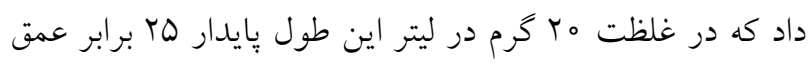
محيط يذيرنده است. در اين غلظت يس از ناحيه تعادلى، غلظت نسبى بين ب/ه تا و/ه مىباشد. ايسن در حسالى اسـت كـه طـول 
ا. سلمانزاده، س. و ج. احديان. ه9با. يُ اكنش حدى جريان جت خروجى در محيط همفاز و غير همفاز، مجلـه علمسى كشـاورزى،

$$
\text { علوم و مهندسى آبيارى هr (1): }
$$

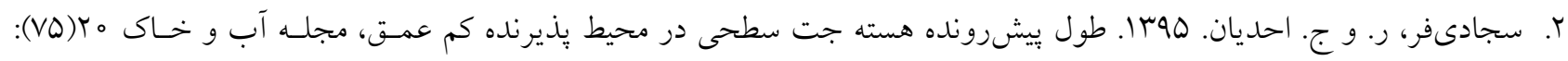

$.141-149$

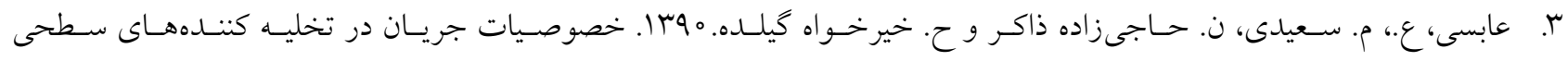
فاضلابهاى سنخين در بِيكره آبى ساكن و لايهبندى نشده. مجله آب و فاضلاب (Y):

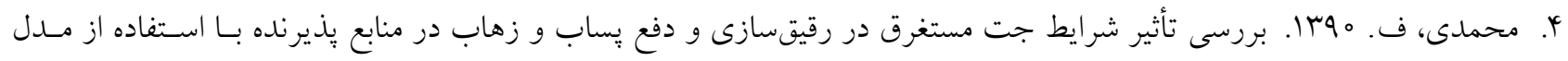
فيزيكى. پايان نامه دكترى، دانشكده مهندسى علوم آب، دانشخاه شهيد جِمران اهواز.

5. Abessi, O., M. Saeedi, T. Bleninger and M. Davidson. 2012. Surface discharge of negatively buoyant effluent in unstratified stagnant water. J. Hydro-Environ. Res. 6(3): 181-193.

6. Abessi, O. and P. J. Roberts. 2015. Dense jet discharges in shallow water. J. of Hydraulic Eng. 142(1): 04015033.

7. Albertson, M. L., Y. B. Dai, R. A. Jensen and H. Rouse. 1950. Diffusion of submerged jets. Transactions of the American Soc. of Civil Eng. 115(1): 639-664.

8. Cipollina, A., A. Brucato, F. Grisafi and S. Nicosia. 2005. Bench-scale investigation of inclined dense jets. J. Hydraulic Eng. 131(11): 1017-1022.

9. Crow, S. C. and F. H. Champagne.1971. Orderly structure in jet turbulence. J. Fluid Mechanics 48(3): $547-591$.

10. Gungor, E. and P. J. Roberts. 2009. Experimental studies on vertical dense jets in a flowing current. J. Hydraulic Eng. 135(11): 935-948.

11. Holley, E. R. and G. H. Jirka. 1986. Mixing in Rivers. US Army Engineer Waterways Experiment Station.

12. Oliver, C. J., M. J. Davidson and R. I. Nokes. 2013. Predicting the near-field mixing of desalination discharges in a stationary environment. Desalination 309: 148-155.

13. Roberts, P. J., A. Ferrier and G. Daviero. 1997. Mixing in inclined dense jets. J. Hydraulic Eng. 123(8): 693-699.

14. Zeitoun, M. 1972. Model Studies of Outfall Systems for Desalination Plants. Part III. Numerical Simulation and Design Considerations.

15. Zhang, H. and R. E. Baddour. 1998. Maximum penetration of vertical round dense jets at small and large Froude numbers. J. Hydraulic Eng. 124(5): 550-553.

16. Zhang, W. and D. Z. Zhu. 2014. Trajectories of Air-Water Bubbly Jets in Crossflows. J. Hydraulic Eng. 140(7): 06014011. 


\title{
Investigating the Discharge Conditions of the Circular Buoyant Co-flow Jet in the Infinitely Shallow Water
}

\author{
B. Mardasi and J. Ahadiyan ${ }^{1^{*}}$
}

(Received: Sept. 24-2016; Accepted: April 18-2017)

\begin{abstract}
Discharge of contaminants in the acceptor ambient has negative environmental impacts. Extremely shallow acceptor ambient conditions will have a significant impact on the diffusion of the contaminants flow. To achieve the effect of the hydraulic, geometric and environmental conditions of the contaminant flow in the acceptor ambient, an experimental model of surface draining was applied. The model consisted of a flume with 3.2 meters length, 0.6 meters width and 0.9 height. Accordingly, by considering three simple single drainers with the diameters of 1.2, 1.6 and 2.2 centimeters, a dense flow with 20, 40 and $60 \mathrm{~g} / \mathrm{L}$ concentrations occurred in an acceptor ambient with H/d $=2$. The results showed that equilibrium length was extremely decreased by increasing the concentrations; this was such that with increasing the concentration three times from 20 to $60 \mathrm{~g} / \mathrm{L}$, this length was decreased from 25 to 10 . However, based on the results, it was found that the effect of the changes of the viscosity parameter over the relative length was significant, as its effect was high in all concentrations to 100; then it tended to become a constant value.. In this regard, the effect of changes in the surface tension parameters over the relative length was investigated; the results showed that this parameter was always effective in the extremely shallow acceptor ambient at all stages from the beginning to the end of the progress. It is important to note that this had a constant slope in all concentrations and surface tension had an effect on flow diffusion with a certain trend in all concentrations. In fact, surface tension in all concentrations reached to 5 after the equilibrium length and jet energy dissipation area.
\end{abstract}

Keywords: Circular Jet, Diffusion, Infinite shallow water, Density Surrounding.

1. Faculty of Water Sci. Eng., Shahid Chamran Univ. of Ahvaz, Iran.

*: Corresponding Author, Email: ja_ahadiyan@yahoo.com 